\title{
EFFECT OF BIOLOGICALLY TREATED SUGAR BEET PULP ON CHEMICAL COMPOSITION, NUTRIENTS DISAPPEARANCE, DIGESTIBIUTY, RUMEN FERMENTATION, RUMEN MICROBES AND SOME BLOOD COMPOSITION IN ADULT SHEEP \\ Hend, A. Aziz \\ Animal Nutrition Department, Desert Research Center, Cairo, Egypt.
}

ABSTRACT

In this study three experiments were conducted, the $1^{\text {st }}$ (a laboratory experiment) included nine treatments (T1-T9) to study the effect of using biological treatments (fungal, bacterial, yeast or yeast combined with fungi or bacteria) on chemical composition and fiber constituents of sugar beet pulp (SBP) to choose the best biological treatments for testing in the $2^{\text {nd }}$ experiment (in vitro experiment). In the $2^{\text {nd }}$ experiment, seven rations containing the best five biologically treated SBP as well as control and untreated SPB rations were used to study the effect of the experimental rations on in vitro chemical composition and nutrients disappearance. These rations included $\mathrm{R} 1$ (control): concentrate feed mixture (CFM) + berseem hay $(\mathrm{BH})$; T2: CFM + untreated SBP+ BH; T3: CFM + SBP treated with S. cerevisiae+ BH; T5: CFM + SBP treated with $T$. viride + BH; T5: CFM + SBP treated with $T$. viride + S. cerevisiae + $\mathrm{BH}$; T6: CFM + SBP treated with $C$. cellulasea $+\mathrm{BH}$, and T7: $\mathrm{CFM}+\mathrm{SBP}$ treated with $\mathrm{C}$. cellulasea $+\mathrm{S}$. cerevisiae $+\mathrm{BH}$. In the $3^{\text {rd }}$ experiment (digestibility experiment) was carried out to study the effect of feeding the same rations on digestibility coefficients, rumen fermentations parameters, microbial protein, protozoal count, number of total bacteria and cellulolytic bacteria and some blood parameters of adult rams. Results revealed that biological treatments increased $(P<0.05) C P$ content and decreased CF, NDF, ADF, ADL content. Digestibility coefficients, concentrations of total volatile fatty acids (TVFA's), total nitrogen, true protein, microbial protein and microbial count increased $(P<0.05)$, nitrogen and water balances improved $(P<0.05)$ in biologically treated SBP as compared to control and untreated SBP rations.

Keywords: Biological treatment, sugar beet pulp, in vivo and in vitro digestibility.

\section{INTRODUCTION}

The shortage of feeds in general attracted the attention of many research workers to use agro-industrial by-products Such as sugar beet pulp (SBP), which is the remaining residues after extraction of sugar beet tubers. This residue comprises $6 \%$ of the total fresh weight of harvested sugar beet (Kjaergaard, 1984). A high proportion of SBP is dried and frequently beet molasses is added before drying. Also, it is available in the local market in a dry unmolassed cubes and it is usually used as an energy source feedstuff for ruminants.

In Egypt there is a developing tendency to increase the sugar production from beet since 1982. The annual amounts of SBP are about 385686 ton (SMA, 2011).

Dried beet pulp is a carbohydrate rich by-product. The protein content of SBP is considered low compared with the requirements of most ruminants and monogastric animals (Israilides et al., 1994). The crude fiber content of beet pulp is considerably high and the content of fast fermentable 
carbohydrates and ether extract are much lower than those of high energy grains (Haaksma, 1982). The cellulose structure of SBP is mainly amorphous, which make it easily hydrolysable (Kjaergaard, 1984) and its pectin content is not covalently linked to a lignified matrix, which make it available source of readily fermentable carbohydrate to enhance the microbial biosynthesis in the rumen (Mansfield et al., 1994).

The impact of feeding dried SBP on rumen fermentation was investigated by many studies (Mansfield et al., 1994; Chikunya et al., 1996; Molina et al., 2000), however, the results did not show clear trend and they were contradictory. On the other hand, no available data on the effect of feeding beet pulp on rumen microbial population and microbial enzymatic activity.

The present work aims to evaluate different biological treatments of SBP in terms of laboratory chemical composition and cell wall constituents ( $1^{\text {st }}$ experiment), to study the effect of the best biological treatments on in vitro chemical composition and nutrient disappearance of rations containing SBP ( $2^{\text {nd }}$ experiment), and digestibility coefficients, nitrogen and water balances and ruminal and blood parameters of sheep ( $3^{\text {rd }}$ experiment).

\section{MATERIALS AND METHODS}

The field experiments were carried out at Maryout Research Station, Desert Research Center, located $35 \mathrm{~km}$ southwest of Alexandria, Egypt.

$1^{\text {st }}$ experiment: "Laboratory study"

This study was designed to evaluate the effect of using various biological treatments (fungal, bacterial, yeast or yeast combined with fungi or bacteria) on chemical composition and fiber constituents of SBP to obtain the best biological treatments for in vitro and in vivo studies. The used biological treatments were obtained from the Microbial Genetic Department, National Research Center, Dokki, Cairo, Egypt. The microorganisms were maintained on agar medium composed of ( $\mathrm{g} / \mathrm{l})$ yeast extract, 3.0; malt extract, 30; peptone, 5.0; sucrose 20 and agar 20. The biological treatments included SBP inoculated with Sacharomyces cerevisiae (T1), Trichoderma viride (T2), $T$. viride + S. cerevisiae (T3), Asarglusorsa (T4), Asarglusorsa + S. cerevisiae (T5), Cellulomonas cellulasea (T6), C. cellulasea + S. cerevisiae (T7), Acetobacter xylinum (T8) and A. xylinum + S. cerevisiae (T9).

An amount of $200 \mathrm{~g}$ of air-dried sugar beet pulp moistened to $60 \%$ and treated with the treatments was incubation for 14 days at $30 \pm 2{ }^{\circ} \mathrm{C}$ for each treatment and the ratio between the combined microorganisms was $1: 1$ with a final moisture content of $60 \%$. Moisture was kept at $60 \%$ and at the end of the inoculation period, samples were oven dried at $70{ }^{\circ} \mathrm{C}$. Product recovery rate (PRR) was calculated according to Nigam (1994).

$2^{\text {nd }}$ experiment: "In vitro study"

This experiment was designed according to the best biological treatment of SBP (fungal, bacterial, yeast or yeast combined with fungi or bacteria), based on their chemical compositions and fiber constituents ( $1^{\text {st }}$ experiment) to study the effect of these treatments on chemical composition, 
cell wall constituents, and in vitro nutrient disappearance of ration including treated or untreated SBP. Seven rations were prepared as follow:

R1 (control): Concentrate feed mixture (CFM) + berseem hay $(B H)$.

$\mathrm{R} 2: \mathrm{CFM}+$ untreated $\mathrm{SBP}+\mathrm{BH}$.

R3: CFM + SBP treated with S. cerevisiae $+\mathrm{BH}$.

R4: $\mathrm{CFM}+\mathrm{SBP}$ treated with $T$. viride $+\mathrm{BH}$.

R5: $\mathrm{CFM}+\mathrm{SBP}$ treated with $T$. viride $+\mathrm{S}$. cerevisiae $+\mathrm{BH}$.

$\mathrm{R} 6 \mathrm{CFM}+\mathrm{SBP}$ treated with C. cellulasea $+\mathrm{BH}$.

R7: CFM + SBP treated with C. cellulasea $+\mathrm{S}$. cerevisiae $+\mathrm{BH}$.

The ratio of CFM to SBP and $\mathrm{BH}$ was $30: 30: 40 \%$ in all treatments.

Ruminal liquor was collected, two hours post feeding from six adult rams fed CFM and good quality $\mathrm{BH}$. Collected ruminal liquor was kept warm in plastic Jug $\left(35-37^{\circ} \mathrm{C}\right)$, strained through two layers of cheese cloth and mixed with urea-buffer under the lab conditions for in vitro studies. The ruminal liquor with the samples of the seven rations, in two replicates for each sample, was incubated for 24 hours to estimate dry matter, organic matter and other nutrients disappearance according to the method described by Terry et al. (1969), modified by Norris (1976).

$3^{\text {rd }}$ experiment: "Digestibility study:

The objective of this experiment was to study the effect of feeding the same rations of the $2^{\text {nd }}$ experiment on digestibility coefficients, rumen fermentations parameters, microbial protein, counts of protozoa, total bacteria, and cellulolytic bacteria, and blood parameters of adult rams.

This experiment lasted 50 days. Twenty eight adult rams were divided into 7 groups (four animals for each) were 7 experimental rations for a month as a palatability and adaptation period for treatments. Then rams were placed in metabolic cages, weighed at the start and the end of the trial. The trial lasted for 20 days from which the first 15 days were considered as an adaptation and preliminary period, followed by 5 days as collection period. Over the collection period, daily amount of feed consumed, residuals, feces, urine and drinking water were individually recorded.

\section{Analytical procedures:}

Proximate chemical and cell wall constituents analyses:

The proximate chemical analysis of the experimental rations was carried out according to the A.O.A.C. (1990) to determine DM, CP, CF and EE, while NFE was obtained by the difference. Also, NDF, ADF and ADL were determined according to the procedures of Van Soest et al. (1991). However, cellulose and hemicelluloses were calculated by the difference between NDF and ADF for hemicelluloses, and between ADF and ADL for cellulose.

\section{Rumen liquor parameters:}

Rumen liquor (RL) samples were obtained at 0,3 and 6 hours post feeding. In $\mathrm{RL}$, ruminal $\mathrm{pH}$ value was immediately measured with $\mathrm{pH}$ meter, while concentrations of ammonia nitrogen, total nitrogen and non-protein nitrogen were determined by the modified semi-micro-kjeldahl digestion method according to A.O.A.C (1990). However, true protein nitrogen concentration was calculated by subtracting the non-protein nitrogen content 
from total nitrogen content. Concentration of total volatile fatty acids (TVFA's) was determined according to Warner (1964).

In addition, count of ruminal ciliate protozoa (Ogimoto and Imai, 1981). Identification of genera and species was according to the description published by Dehority (1993). Dilution series were prepared under $\mathrm{O}_{2}$-free $\mathrm{CO}_{2}$ by the anaerobic method of Bryant (1972) using the anaerobic diluents described by Mann (1968) to determine count of total bacteria and cellulolytic bacteria.

At the end of digestibility trails, blood serum samples were collected pre-feeding and $4 \mathrm{~h}$ post-feeding to determine the concentration of total proteins, albumin, and urea as well as activity of AST and ALT using commercial kits. However, concentration of globulin was obtained by the difference between total protein and albumin.

Statistical analysis:

Data was statistically analyzed according to statistical analysis system of SAS (2000). Data of chemical composition, cell wall constituents analysis, nutrient disappearance, digestibility coefficients, nitrogen balance and water balance were analyzed by one-way analysis and the model was:

\section{$Y i j=M+T i+e i j$}

The used model for rumen fermentation parameters and microbial count was two-way analysisas follows: $Y_{i j}=\mu+T_{i}+l_{j}+T l_{i j}+e_{i j}$

Where: $Y_{i j}=$ experimental observation, $\mu=$ general mean, $T_{i}=$ effect of treatment $(i=1-7$ rations $), l_{j}=$ effect of sampling time $(j=0,3$ and $6 h$ ), $\mathrm{Tl}_{\mathrm{ij}}=$ effect of interaction between treatment or ration, and sampling time and $e_{i j}=$ random error. Separation among means was carried out using Duncan's multiple test (Duncan, 1955).

\section{RESULTS AND DISCUSSION}

\section{$1^{\text {st }}$ experiment: "Laboratory study"}

\section{Chemical and cell wall constituents analyses of various treatments:}

Data presented in Tables (1 and 2) indicated significant difference among treatments on chemical composition and cell wall constituents. Results presented in Table $(1)$ showed that T3 had the highest $(P<0.05) D M$, $\mathrm{OM}, \mathrm{EE}$ and $\mathrm{CP}$ contents, followed by T7, T1, T2 and T6, respectively. However, the highest $(P<0.05)$ values of $C F$ content was for $T 4$ and $T 8$, and the lowest $(P<0.05)$ content was for T3, followed by T7 and T9.

Data of Table (2) showed that NDF, ADF, ADL, cellulose and hemicelluloses decreased $(P<0.05)$ to the lowest values in $T 7$ as compared to other treatments, followed by T9, while T4 showed the highest $(P<0.05)$ values, followed by $\mathrm{T} 8$ and $\mathrm{T} 5$, respectively. The best $(\mathrm{P}<0.05)$ product recovery rate was for T3 $(45.07 \%)$, followed by T7 $(47.42 \%)$, while the lowest $(\mathrm{P}<0.05)$ rate was for T4 $(61.37 \%)$, followed by T8 $(60.11 \%)$. 
Table (1): Effect of various biological treatments on chemical composition of sugar beet pulp.

\begin{tabular}{|l|l|l|l|l|l|l|c|}
\hline \multirow{2}{*}{ Treatment } & \multirow{2}{*}{ DM } & \multicolumn{7}{|c|}{ Chemical composition (\%) } \\
\cline { 3 - 8 } & & OM & Ash & EE & CP & CF & NFE \\
\hline T1 & $93.02^{\mathrm{b}}$ & $92.93^{\mathrm{b}}$ & $7.06^{\mathrm{e}}$ & $2.22^{\mathrm{c}}$ & $20.83^{\mathrm{d}}$ & $19.95^{\mathrm{e}}$ & $50.05^{\mathrm{h}}$ \\
T2 & $92.85^{\mathrm{c}}$ & $92.75^{\mathrm{cd}}$ & $7.25^{\mathrm{cd}}$ & $2.12^{\mathrm{d}}$ & $20.27^{\mathrm{e}}$ & $19.99^{\mathrm{ed}}$ & $50.48^{\mathrm{g}}$ \\
T3 & $93.44^{\mathrm{a}}$ & $93.10^{\mathrm{a}}$ & $6.89^{\mathrm{f}}$ & $2.68^{\mathrm{a}}$ & $22.33^{\mathrm{a}}$ & $17.27^{\mathrm{h}}$ & $50.92^{\mathrm{e}}$ \\
T4 & $92.17^{\mathrm{g}}$ & $92.07^{\mathrm{f}}$ & $7.92^{\mathrm{a}}$ & $1.79^{\mathrm{f}}$ & $16.89^{\mathrm{i}}$ & $21.07^{\mathrm{a}}$ & $52.42^{\mathrm{b}}$ \\
T5 & $92.45^{\mathrm{f}}$ & $92.55^{\mathrm{e}}$ & $7.45^{\mathrm{b}}$ & $1.89^{\mathrm{e}}$ & $17.25^{\mathrm{h}}$ & $20.07^{\mathrm{c}}$ & $53.48^{\mathrm{a}}$ \\
T6 & $92.81^{\mathrm{cd}}$ & $92.90^{\mathrm{b}}$ & $7.09^{\mathrm{e}}$ & $2.11^{\mathrm{d}}$ & $20.15^{\mathrm{f}}$ & $20.06^{\mathrm{cd}}$ & $50.75^{\mathrm{f}}$ \\
T7 & $93.01^{\mathrm{b}}$ & $92.91^{\mathrm{b}}$ & $7.09^{\mathrm{e}}$ & $2.36^{\mathrm{b}}$ & $21.87^{\mathrm{b}}$ & $17.466^{\mathrm{g}}$ & $51.36^{\mathrm{d}}$ \\
T8 & $92.63^{\mathrm{e}}$ & $92.72^{\mathrm{d}}$ & $7.27^{\mathrm{c}}$ & $1.93^{\mathrm{e}}$ & $19.07^{\mathrm{g}}$ & $20.19^{\mathrm{b}}$ & $51.65^{\mathrm{c}}$ \\
T9 & $92.74^{\mathrm{d}}$ & $92.82^{\mathrm{c}}$ & $7.18^{\mathrm{d}}$ & $2.23^{\mathrm{c}}$ & $21.15^{\mathrm{c}}$ & $18.65^{\mathrm{f}}$ & $50.93^{\mathrm{e}}$ \\
IMSE & 0.025 & 0.025 & 0.025 & 0.016 & 0.021 & 0.023 & 0.022 \\
\hline
\end{tabular}

Means with different litters with each column are significantly different $(P<0.05) . T 1$ : SBP with S. cerevisiae. T2: SBP with $T$. viride. T3: SBP with $T$. viride + S. cerevisiae.

T4: SBP with $A$. orsa. T5: SBP with A. orsa + S. cerevisiae. T6: SBP with C. cellulasea. T7: SBP with C. cellulasea + S. cerevisiae. T8: SBP with A. xylinum.

T9: SBP with A. xylinum + S. cerevisiae.

Table (2): Effect of various biological treatments on cell wall constituents and product recovery (\%) of sugar beet pulp.

\begin{tabular}{|c|c|c|c|c|c|c|}
\hline \multirow[b]{2}{*}{ Treat. } & \multicolumn{5}{|c|}{ Cell wall constituent } & \multirow{2}{*}{$\begin{array}{c}\text { Product } \\
\text { Recovery }(\%)\end{array}$} \\
\hline & NDF & ADF & ADL & $\begin{array}{c}\text { Cellulos } \\
\text { e }\end{array}$ & $\begin{array}{c}\text { Hemicellulos } \\
\text { e }\end{array}$ & \\
\hline$\overline{\Gamma 1}$ & $54.02^{f}$ & $24.37^{e}$ & $1.94^{\mathrm{e}}$ & $29.64^{b}$ & $22.43^{c}$ & $55.12^{\mathrm{e}}$ \\
\hline T2 & $54.15^{\mathrm{e}}$ & $24.97^{d}$ & $2.02^{\mathrm{d}}$ & $29.18^{c}$ & $22.95^{\mathrm{b}}$ & $57.68^{d}$ \\
\hline T3 & $50.05^{i}$ & $22.65^{\mathrm{g}}$ & $1.82^{f}$ & $27.40^{e}$ & $20.83^{e}$ & $45.07^{i}$ \\
\hline T4 & $56.37^{a}$ & $26.30^{a}$ & $2.36^{a}$ & $30.07^{a}$ & $23.94^{a}$ & $61.37^{a}$ \\
\hline T5 & $54.48^{c}$ & $25.25^{c}$ & $2.28^{b}$ & $29.23^{c}$ & $22.97^{b}$ & $50.82^{f}$ \\
\hline T6 & $54.25^{d}$ & $25.08^{\mathrm{cd}}$ & $2.17^{\mathrm{c}}$ & $29.17^{c}$ & $22.90^{\mathrm{b}}$ & $58.40^{c}$ \\
\hline T7 & $50.42^{\mathrm{h}}$ & $22.42^{\mathrm{h}}$ & $1.86^{f}$ & $28.00^{d}$ & $20.56^{f}$ & $45.60^{h}$ \\
\hline T8 & $55.25^{\mathrm{b}}$ & $25.96^{b}$ & $2.19 \mathrm{c}$ & $29.29 c$ & $23.77^{a}$ & $60.11^{\mathrm{b}}$ \\
\hline T9 & $51.98^{g}$ & $23.91^{f}$ & $1.93^{e}$ & $28.07^{d}$ & $21.98^{d}$ & $47.32^{\mathrm{g}}$ \\
\hline EMSE & 0.022 & 0.062 & 0.015 & 0.061 & 0.053 & 0.036 \\
\hline
\end{tabular}

Similar results were obtained by El-Ashry et al. (2002 and 2003) and Kholif et al. (2005), who indicated that the fungal treatment led to increase CP and decreased CF and OM contents. Based on these results, six treatments beside control were used in the following in vitro and in vivo studies.

$2^{\text {nd }}$ treatment: "In vitro study"

Chemical composition and cell wall constituents:

Data presented in Table (3) revealed significant $(P<0.05)$ effect of treatment on chemical composition and cell wall constituents. All biological treatments of SBP increased DM, OM, EE and CP contents as compared to untreated SBP; the highest $(P<0.05)$ contents were in $R 5$, followed by $R 7$. It 
is important to show that all biological treatments that showed marked increase $(P<0.05)$ in $C P$ content and pronounced decrease $(P<0.05)$ in $C F$, NDF, ADF, ADL, cellulose and hemicellulose contents as compared to ration containing untreated SBP (R2). Similar results were recorded by Israilides et al. (1994), who found that CP content of beet pulp was increased from 9.96 to $19.50 \%$ by fungal treatments. Also, Abedo et al. (2005) found that fungal treatment with Trichoderm aressei increased the CP content of SBP from 9.94 to $19.37 \%$ and ether extract from 0.64 to $0.88 \%$. While CF, ADF, ADL and cellulose contents increased and NDF and hemicellulose were decreased by fungal treatment.

Table (3): Chemical composition and cell wall constituents of rations containing biologically treated sugar beet pulp during in vitro study.

\begin{tabular}{|c|c|c|c|c|c|c|c|c|}
\hline Item & R1 & $\mathbf{R 2}$ & R3 & R4 & R5 & R6 & R7 & \pm MSE \\
\hline DM (\%) & $92.80^{\mathrm{a}}$ & $89.02^{9}$ & $90.72^{d}$ & $90.05^{\mathrm{e}}$ & $91.75^{b}$ & $89.94^{f}$ & $91.40^{\mathrm{c}}$ & 0.021 \\
\hline \multicolumn{9}{|c|}{ Chemical composition (\%): } \\
\hline OM & $88.19^{c}$ & $86.44^{9}$ & $88.04^{\mathrm{d}}$ & $87.49^{f}$ & $90.45^{a}$ & $87.74^{\mathrm{e}}$ & $90.00^{\mathrm{b}}$ & 0.021 \\
\hline $\mathrm{CP}$ & $13.36^{f}$ & $10.26^{g}$ & $17.28^{\mathrm{c}}$ & $16.68^{\mathrm{d}}$ & $18.67^{a}$ & $16.47^{\mathrm{e}}$ & $18.15^{b}$ & 0.011 \\
\hline CF & $20.06^{c}$ & $23.40^{\mathrm{a}}$ & $20.06^{c}$ & $20.93^{b}$ & $18.26^{f}$ & $19.77^{d}$ & $18.66^{\mathrm{e}}$ & 0.011 \\
\hline $\mathrm{EE}$ & $2.09^{f}$ & $2.55^{\mathrm{e}}$ & $2.88^{\mathrm{c}}$ & $2.85^{\mathrm{c}}$ & $3.88^{\mathrm{a}}$ & $2.69^{d}$ & $3.66^{b}$ & 0.018 \\
\hline NFE & $52.83^{a}$ & $50.41^{\mathrm{b}}$ & $47.97 \mathrm{f}$ & $47.25 \mathrm{~g}$ & $49.78^{c}$ & $48.95^{\mathrm{e}}$ & $49.70^{d}$ & 0.011 \\
\hline Ash & $11.80^{\mathrm{e}}$ & $13.55^{\mathrm{a}}$ & $11.96^{\mathrm{d}}$ & $12.51^{b}$ & $9.55^{9}$ & $12.25^{\mathrm{c}}$ & $10.00^{f}$ & 0.021 \\
\hline \multicolumn{9}{|c|}{ Cell wall constituents $(\%)$ : } \\
\hline NDF & $54.23^{f}$ & $71.95^{\mathrm{a}}$ & $63.45^{\mathrm{c}}$ & $64.15^{b}$ & $56.48^{\mathrm{e}}$ & $62.36^{d}$ & $54.26^{f}$ & 0.011 \\
\hline ADF & $25.08^{\mathrm{g}}$ & $43.31^{\mathrm{a}}$ & $38.16^{d}$ & $40.07^{b}$ & $32.66^{\mathrm{e}}$ & $39.30^{c}$ & $31.32^{\mathrm{f}}$ & 0.027 \\
\hline ADL & $2.17^{f}$ & $6.98^{\mathrm{a}}$ & $5.46^{\mathrm{c}}$ & $5.86^{\mathrm{b}}$ & $4.87^{\mathrm{d}}$ & $5.47^{\mathrm{c}}$ & $4.21^{\mathrm{e}}$ & 0.016 \\
\hline CS & $29.15^{a}$ & $28.64^{b}$ & $25.28^{\mathrm{c}}$ & $24.07^{d}$ & $23.82^{\mathrm{e}}$ & $23.06^{\mathrm{f}}$ & $22.93^{9}$ & 0.031 \\
\hline HCS & $22.90^{9}$ & $36.33^{\mathrm{a}}$ & $32.70^{\mathrm{d}}$ & $34.21^{b}$ & $27.78^{\mathrm{e}}$ & $33.83^{\mathrm{c}}$ & $27.11^{f}$ & 0.029 \\
\hline
\end{tabular}

Means with different litters with each row are significantly different $(P<0.05)$.

R1 (control): CFM+BH. R2: CFM + untreated SBP+BH. R3: CFM+BH+SBP treated with $S$. cerevisiae. R4: $\mathrm{CFM}+\mathrm{BH}+\mathrm{SBP}$ treated with $T$. viride. R5: $\mathrm{CFM+BH+SBP}$ treated with $T$. viride + S. cerevisiae. R6: $\mathrm{CFM+BH+SBP}$ treated with C. cellulasea. R7: $\mathrm{CFM+BH+SBP}$ treated with C. cellulasea+S. cerevisiae. CS: Cellulose. HCS: Hemicellulose.

\section{Nutrient disappearance:}

Data in Table (4) revealed a significant $(P<0.05)$ differences in nutrient and cell wall constituents between different experimental rations. It is worthy noting that biological treatments of SBP increased $(P<0.05)$ disappearance of DM, OM, EE, CP, CF, NFE, NDF, ADF, ADL, cellulose and hemicellulose as compared to untreated SBP and control. In this respect, R5 had the highest disappearance of DM, OM, EE, CP, NFE, NDF and cellulose, while R7 had the highest disappearance of CF, ADF, ADL and hemicellulose.

Results revealed also that combination of yeast with fungi or bacteria enhanced the disappearance of most nutrients as compared to each one alone. Similar results were obtained by El-Ashry et al. (2003), who reported that biological treatment of poor quality roughages by $T$. viride, Pencillium funiculosium and S. cerevisiae increased DM and OM in vitro disappearance. Also, Colombatto et al. (2003) found that fibrolytic enzymes secreted by 
cellulolytic bacteria enhanced the fermentation of cellulose and xylan. Moreover, Gado and Abd El-Galil (2009) showed that cellulolytic bacteria strains isolated from sheep was more effective in increased the in vitro DM disappearance because these active strains were secreted cellulase enzymes most effective on roughage than other strains.

Table (4): Nutrient disappearance (\%) of ration containing biologically treated sugar beet pulp during in vitro study.

\begin{tabular}{|l|c|c|c|c|c|c|c|c|}
\hline \multirow{2}{*}{ Item } & \multicolumn{7}{|c|}{ Treatment } & \multirow{2}{*}{ IMSE } \\
\cline { 2 - 7 } & $\mathbf{R 1}$ & $\mathbf{R 2}$ & $\mathbf{R 3}$ & $\mathbf{R 4}$ & $\mathbf{R 5}$ & $\mathbf{R 6}$ & $\mathbf{R 7}$ & \\
\hline DM & $63.68^{\mathrm{f}}$ & $61.22^{\mathrm{g}}$ & $69.43^{\mathrm{d}}$ & $70.20^{\mathrm{c}}$ & $80.89^{\mathrm{a}}$ & $66.84^{\mathrm{e}}$ & $79.88^{\mathrm{b}}$ & 0.010 \\
\hline Chemical composition (\%): \\
\hline OM & $64.25^{\mathrm{f}}$ & $64.38^{\mathrm{f}}$ & $69.97^{\mathrm{e}}$ & $71.75^{\mathrm{d}}$ & $84.41^{\mathrm{a}}$ & $73.70^{\mathrm{c}}$ & $77.31^{\mathrm{b}}$ & 0.073 \\
EE & $50.27^{\mathrm{e}}$ & $56.10^{\mathrm{d}}$ & $65.44^{\mathrm{c}}$ & $63.63^{\mathrm{c}}$ & $79.90^{\mathrm{a}}$ & $63.08^{\mathrm{c}}$ & $76.58^{\mathrm{b}}$ & 10.78 \\
CP & $78.44^{\mathrm{g}}$ & $85.42^{\mathrm{d}}$ & $87.62^{\mathrm{c}}$ & $84.57^{\mathrm{f}}$ & $90.65^{\mathrm{a}}$ & $85.20^{\mathrm{e}}$ & $89.05^{\mathrm{b}}$ & 0.022 \\
CF & $69.80^{\mathrm{f}}$ & $55.06^{\mathrm{g}}$ & $71.79^{\mathrm{d}}$ & $71.19^{\mathrm{e}}$ & $83.09^{\mathrm{b}}$ & $75.98^{\mathrm{c}}$ & $85.55^{\mathrm{a}}$ & 0.024 \\
NFE & $59.31^{\mathrm{f}}$ & $64.80^{\mathrm{d}}$ & $63.52^{\mathrm{e}}$ & $67.91^{\mathrm{c}}$ & $82.87^{\mathrm{a}}$ & $69.50^{\mathrm{b}}$ & $69.94^{\mathrm{b}}$ & 0.167 \\
\hline Cell wall constituents (\%): \\
\hline NDF & $67.86^{\mathrm{f}}$ & $64.96^{\mathrm{g}}$ & $75.71^{\mathrm{e}}$ & $76.51^{\mathrm{d}}$ & $83.18^{\mathrm{a}}$ & $76.86^{\mathrm{c}}$ & $81.41^{\mathrm{b}}$ & 0.025 \\
ADF & $75.58^{\mathrm{f}}$ & $69.04^{\mathrm{g}}$ & $76.75^{\mathrm{e}}$ & $77.57^{\mathrm{d}}$ & $81.32^{\mathrm{b}}$ & $80.01^{\mathrm{c}}$ & $87.85^{\mathrm{a}}$ & 0.017 \\
ADL & $53.54^{\mathrm{f}}$ & $52.40^{\mathrm{g}}$ & $67.76^{\mathrm{d}}$ & $66.56^{\mathrm{e}}$ & $84.59^{\mathrm{b}}$ & $69.40^{\mathrm{c}}$ & $86.30^{\mathrm{a}}$ & 0.022 \\
CS & $61.31^{\mathrm{f}}$ & $58.84^{\mathrm{g}}$ & $74.07^{\mathrm{c}}$ & $74.63^{\mathrm{b}}$ & $85.80^{\mathrm{a}}$ & $71.59^{\mathrm{e}}$ & $72.65^{\mathrm{d}}$ & 0.029 \\
HCS & $77.63^{\mathrm{f}}$ & $72.21^{\mathrm{g}}$ & $78.21^{\mathrm{e}}$ & $78.50^{\mathrm{d}}$ & $84.40^{\mathrm{b}}$ & $81.74^{\mathrm{c}}$ & $88.07^{\mathrm{a}}$ & 0.022 \\
\hline
\end{tabular}

Means with different litters with each row are significantly different $(P<0.05)$.

CS: Cellulose. HCS: Hemicellulose.

$3^{\text {rd }}$ experiment: "Digestibility study"

Chemical composition and cell wall constituents:

Data in Tables (5\& 6) indicated the same trend of chemical composition and cell wall constituents of the experimental rations as obtained in the $2^{\text {nd }}$ study. The control ration $(R 1)$ showed the highest $(P<0.05)$ contents of DM, OM, EE and NFE as compared to untreated or treated SBP rations. However, contents of DM, EE and CP were higher $(P<0.05)$ in all biological treated rations than in untreated SBP ration (R2). On the other hand, contents of OM, CF, NDF, ADF, ADL, cellulose and hemicellulose decreased $(P<0.05)$ in treated SBP rations more than in untreated one. Generally, R5 and R7 had the highest content of CP and the lowest content of CF and its fraction. The increased CP content by biological treatments may be due to the increase in rumen microorganisms (protozoa and bacteria), which are consume CP of the diet to convert it into microbial protein. While, the observed decrease of CF content by progressed time of incubation may be due to the microbial digestion by cellulolytic bacteria which secreted cellulase enzymes to degrade crude fiber, or due to the utilization of CF by fungi for their growth since fungi among the microorganisms have been proved its capability in decomposing the agricultural by-products as several strains of fungi were used by many researchers for lignocellulosic hydrolyses such as Aspergillusniger, Funsarium moniliforme and Trichoderma viride. 
The present results are in agreement with Allam et al. (2006), who found that replacing $100 \%$ of corn grains in the CFM of lambs by SBP treated with Trichoderma viride and Sacharomyces cerevisiae decreased contents of $\mathrm{OM}, \mathrm{CF}$, hemicellulose, cellulose, lignin and pectin, while CP and true protein contents were increased as compared to control ration. Also, El-Badawi et al. (2007) reported that SBP treated with $T$. ressei decreased OM content and increased CP content.

Table (5): Effect of treatments on chemical composition during digestibility trails.

\begin{tabular}{|c|c|c|c|c|c|c|c|}
\hline \multirow{2}{*}{ Item } & \multirow{2}{*}{ DM (\%) } & \multicolumn{6}{|c|}{ Chemical composition (\%) } \\
\hline & & OM & Ash & CP & CF & EE & NFE \\
\hline \multicolumn{8}{|l|}{ Ration: } \\
\hline R1 & $93.80^{a}$ & $91.96^{a}$ & $8.04^{g}$ & $12.51^{\mathrm{b}}$ & $11.37^{d}$ & $3.15^{a}$ & $65.11^{a}$ \\
\hline $\mathrm{R} 2$ & $89.07^{\mathrm{g}}$ & $90.69^{b}$ & $9.31^{f}$ & $10.88^{b}$ & $17.90^{\mathrm{a}}$ & $2.17^{d}$ & $59.91^{\mathrm{b}}$ \\
\hline R3 & $92.75^{d}$ & $89.00^{e}$ & $10.99^{c}$ & $19.04^{a}$ & $17.18^{\mathrm{ab}}$ & $2.49^{c}$ & $50.51^{\mathrm{c}}$ \\
\hline R4 & $92.36^{e}$ & $89.75^{d}$ & $10.25^{d}$ & $16.40^{\mathrm{a}}$ & $15.69^{b c}$ & $2.61^{c}$ & $55.23^{b c}$ \\
\hline R5 & $93.62^{\mathrm{b}}$ & $87.04^{\mathrm{g}}$ & $12.96^{\mathrm{a}}$ & $17.45^{\mathrm{a}}$ & $14.30^{c}$ & $2.92^{\mathrm{ab}}$ & $52.56^{\mathrm{c}}$ \\
\hline R6 & $91.99^{f}$ & $89.93^{c}$ & $10.06^{\mathrm{e}}$ & $16.35^{\mathrm{a}}$ & $15.69^{b c}$ & $2.62^{\mathrm{c}}$ & $55.46^{\mathrm{bc}}$ \\
\hline $\mathrm{R} 7$ & $93.39^{c}$ & $88.82^{f}$ & $11.18^{\mathrm{b}}$ & $17.20^{\mathrm{a}}$ & $14.39^{c}$ & $2.75^{\mathrm{cb}}$ & $54.65^{c}$ \\
\hline$\pm \mathrm{MSE}$ & 0.020 & 0.007 & 0.007 & 0.883 & 0.576 & 0.073 & 1.396 \\
\hline \multicolumn{8}{|c|}{ Feedstuff: } \\
\hline CFM & 93.80 & 92.00 & 8.00 & 12.49 & 11.32 & 3.10 & 65.09 \\
\hline Hay & 91.24 & 88.01 & 11.99 & 14.00 & 26.61 & 2.55 & 44.85 \\
\hline USBP & 91.10 & 95.60 & 4.40 & 9.20 & 24.40 & 1.18 & 60.82 \\
\hline
\end{tabular}

Means with different litters with each column are significantly different $(P<0.05)$. CFM: Concentrte feed mixure. USBP: Untreated SBP.

Table (6): Effect of treatments on cell wall constituents during digestibility experiment.

\begin{tabular}{|c|c|c|c|c|c|}
\hline \multirow{2}{*}{ Item } & \multicolumn{5}{|c|}{ Cell wall constituents (\%) } \\
\hline & NDF & ADF & ADL & Cellulose & Hemicellulose \\
\hline \multicolumn{6}{|l|}{ Ration: } \\
\hline R1 & $31.01^{f}$ & $17.80^{\mathrm{g}}$ & $4.89^{a}$ & $13.20^{f}$ & $12.91^{f}$ \\
\hline $\mathrm{R} 2$ & $47.61^{\mathrm{a}}$ & $24.18^{a}$ & $4.16^{b}$ & $23.43^{a}$ & $20.02^{a}$ \\
\hline R3 & $42.53^{c}$ & $21.07^{d}$ & $3.45^{\mathrm{e}}$ & $21.46^{b}$ & $17.63^{c}$ \\
\hline R4 & $42.59^{b}$ & $21.37^{c}$ & $3.49^{d}$ & $21.21^{\mathrm{c}}$ & $17.88^{\mathrm{b}}$ \\
\hline R5 & $40.55^{e}$ & $20.20^{e}$ & $3.36^{f}$ & $20.35^{e}$ & $16.83^{d}$ \\
\hline R6 & $42.61^{b}$ & $21.45^{b}$ & $3.55^{c}$ & $21.16^{c}$ & $17.90^{b}$ \\
\hline $\mathrm{R} 7$ & $40.71^{d}$ & $20.10^{f}$ & $3.38^{f}$ & $20.61^{d}$ & $16.72^{\mathrm{e}}$ \\
\hline \pm MSE & 0.010 & 0.013 & 0.008 & 0.021 & 0.018 \\
\hline \multicolumn{6}{|l|}{ Feedstuff: } \\
\hline CFM & 30.98 & 17.75 & 4.86 & 13.23 & 12.89 \\
\hline Hay & 62.96 & 44.44 & 7.13 & 18.52 & 37.31 \\
\hline USBP & 60.42 & 29.05 & 2.84 & 31.37 & 26.21 \\
\hline
\end{tabular}

Means with different litters with each column are significantly different $(P<0.05)$. USBP: Untreated SBP. 


\section{Digestibility coefficients and nutritive values:}

Data in Table (7) showed that biological treatments decreased $(P<0.05)$ feed intake compared to untreated and control rations, being the lowest $(P<0.05)$ for $R 5$, followed by $R 7$, but the differences among $R 7, R 6$, R3, and R4 were not significant. Conflicted results were obtained by several authors. In this line, Kholif et al. (2005) and Aziz (2009) reported that biological treatment slightly increased DM intake, while, Rode et al. (1999) and Yang et al. (1999) reported that fungal or enzymatic treatments did not alter DM intake.

Regarding the results of digestibility trails (Table 7 ), it seems that biological treatments, particularly in $R 5$ and $R 7$ significantly $(P<0.05)$ increased digestibility coefficients of all nutrients and most cell wall constituents as compared to control and untreated rations. The improvement of DM digestibility in treated rations might be due to the better palatability of biologically treated SBP compared with untreated SBP and/or better utilization by the host animal. In this respect, Khampa et al. (2009) reported higher nutrient digestibilities as a result of yeast supplementation, which could be related to the microbial activities which solubilizing of carbohydrate esters of phenolic monomers in the cell wall. Also, Zadrazil (1984) mentioned that white rot fungi are able to increase the digestibility of plant residues without chemical and physical pretreatment through selective lignin degradation.

In addition, several authors observed an improvement in DM, CP and CF digestibility coefficients over a wide range of low quality roughages treated by biological treatments (Deraz and Ismail, 2001; Mahrous and Abou Ammou, 2005; Aziz 2009). Moreover, Allam et al. (2006) reported that SBP treated with Trichoderma viride and Sacharomyces cerevisiae increased DM, $\mathrm{OM}, \mathrm{CF}$ and fiber fraction (NDF, ADF, cellulose and ADL) digestibilities, while $\mathrm{CP}$ and EE digestibility coefficients were not affected.

On the other hand, data of nutritive values (Table 7) showed significant $(P<0.05)$ differences among treatments. Control ration $(R 1)$ showed the highest TDN (g/h/d, g/kg BW and $\mathrm{g} / \mathrm{kg} \mathrm{BW}{ }^{0.75}$ ), followed by untreated SBP ration (R2), but the differences among R2 and biologically treated SBP rations were not significant $(P \leq 0.05)$. Only R5 and R7 showed the highest $(\mathrm{P}<0.05)$ TDN\% of DM intake as compared to untreated ration (R2), but did not differ from R1.

Data in Table $(7)$ showed that $R 7$ significantly $(P<0.05)$ increased nutritive values of DCP $\left(\mathrm{g} / \mathrm{h} / \mathrm{d}, \mathrm{g} / \mathrm{h} / \mathrm{BW}\right.$ and $\left.\mathrm{g} / \mathrm{kg} \mathrm{BW}^{0.75}\right)$ as compared to control and untreated SBP rations. However, nutritive value in term of DCP\% of DMI was significantly $(P<0.05)$ the highest for $R 5$, followed by $R 7$. However, the differences in metabolic energy (ME/g TDN) among the experimental rations were not significant.

Based on the foregoing results, biological treatments of SBP increased nutritive values (TDN and DCP). These improvements are associated with the increased digestion in fibrous materials particularly hemicellulose in addition to the increased bacterial digestion of cell wall content (Hassan et al., 2005). Also, these results reflected the values 
obtained for rations digestibility which were higher for treated rations compared with the untreated rations

Similar results were obtained by Khorshed (2000); Hassan et al. (2005); Gado et al. (2006) and Aziz (2009), who reported that the nutritive value as TDN and DCP were significantly higher $(P<0.05)$ in biologically treated agriculture by-products.

Nitrogen balance:

Data in Table (8) showed that biological treatments increased $(P<0.05)$ nitrogen intake $(\mathrm{NI})$ and digested nitrogen $(\mathrm{DN})$ values $(\mathrm{g} / \mathrm{h} / \mathrm{d})$ more than control and untreated SBP rations. The highest $(P<0.05) \mathrm{NI}$ and DN values $(\mathrm{g} / \mathrm{h} / \mathrm{d})$ were recorded for $\mathrm{R} 7$, followed by $\mathrm{R} 6$ and $\mathrm{R} 3$ with insignificant differences. Although, the differences in $\mathrm{NI}$ and DN values as $\mathrm{g} / \mathrm{kg} \mathrm{BW}$ or $\mathrm{g} / \mathrm{kg} \mathrm{BW} \mathrm{BW}^{0.75}$ were not significant $(\mathrm{P}<0.05)$ among control and biologically treated rations, $\mathrm{DN}$ as a percentage of $\mathrm{NI}$ showed the same trend, whereas R5 had the highest $(\mathrm{P}<0.05)$ value $(92.71 \%)$ of $\mathrm{DN} \%$ of $\mathrm{NI}$, followed by $\mathrm{T} 7$ $(90.54 \%)$, while, the lowest one was for untreated SBP (72.51). Fecal and urinary nitrogen excretion $(\mathrm{g} / \mathrm{h} / \mathrm{d}, \mathrm{g} / \mathrm{kg} \mathrm{BW}, \mathrm{g} / \mathrm{kg} \mathrm{BW} 0.75$ and $\%$ of $\mathrm{NI})$ were the highest $(P<0.05)$ for control, followed by untreated SBP ration.

Therefore, they also had the highest total nitrogen excretion values as $\mathrm{g} / \mathrm{h} / \mathrm{d}$, $\mathrm{g} / \mathrm{kg} \mathrm{BW}, \mathrm{g} / \mathrm{kg} \mathrm{BW} 0.75$, \% of $\mathrm{NI}$. While, R5 had the lowest value \% of $\mathrm{NI}$ $(27.38 \%)$. Biological treatments increased $(P<0.05)$ nitrogen balance $(\mathrm{g} / \mathrm{h} / \mathrm{d}$, $\mathrm{g} / \mathrm{kg} \mathrm{BW}, \mathrm{g} / \mathrm{kg} \mathrm{BW}^{0.75}, \%$ of $\mathrm{NI}$ and \% of DN) more than control and untreated SBP, being the highest for R5 and R7.

It is clear that biological treatments of SBP increased nitrogen balance more than untreated USB and control rations containing 60\% CFM and $40 \% \mathrm{BH}$. This improvement was attributed to less nitrogen excretion, the improvement in rumen fermentation especially ruminal ammonia, NPN, total nitrogen and true protein nitrogen. These results are in agreement with those obtained by Allam et al. (2006), who reported that biologically treated SBP with Trichoderma viride and Sacharomyces cerevisiae had the highest value of nitrogen balance and NB/IN. 
J.Animal and Poultry Prod., Mansoura Univ., Vol. 5 (12), December, 2014

7 
Hend, A. Aziz 


\section{Water balance:}

Data in Table $(9)$ showed insignificant $(P<0.05)$ differences in free drinking water and total water intake $\left(\mathrm{ml} / \mathrm{h} / \mathrm{d}\right.$ or $\left.\mathrm{ml} / \mathrm{Kg} \mathrm{W}^{0.82}\right)$, although $\mathrm{R} 1$ and $R 2$ had the highest $(P<0.05)$ values of combined and metabolic water $(\mathrm{ml} / \mathrm{h} / \mathrm{d}$ or $\left.\mathrm{ml} / \mathrm{Kg} \mathrm{W}^{0.82}\right)$. Biological treatments decreased $(\mathrm{P}<0.05)$ urinary water, fecal water and total water execration $\left(\mathrm{ml} / \mathrm{h} / \mathrm{d}\right.$ or $\mathrm{ml} / \mathrm{Kg} \mathrm{W}{ }^{0.82}$ ) more than $\mathrm{R} 1$ and R2. The lowest values were for R5, followed by R7. Water balance showed insignificant $(\mathrm{P}<0.05)$ differences among all treatments, although, biological treatments had slightly higher values. Both R5 followed by R7 had the highest water balance as a percentage of water intake, being 90.26 and $89.00 \%$ of intake, respectively.

Subhash et al. (1991) reported that the values of water intake (liters/day) were varied between (3.17 and 4.15) for diets which contained paddy straw and fungal treated paddy straw.

\section{Rumen parameters:}

Data in Table (10) showed that biological treatments decreased $(\mathrm{P}<0.01)$ ruminal $\mathrm{pH}$ values and increased $(\mathrm{P}<0.05)$ total volatile fatty acids (TVFA's) ruminal liquor (RL) as compared to control and untreated rations. In this way, $\mathrm{R}$, R5 showed the lowest $\mathrm{pH}(6.37, \mathrm{P}<0.05)$ and the highest TVFA's concentration as compared to control and untreated SBP rations.

These results indicated the negative relationship between $\mathrm{pH}$ value and TVFA's concentration for each ration. Fouad (1991) concluded that the rumen $\mathrm{pH}$ in general decreased with increasing the TVFA's concentration in lambs rumen.

Results of molar proportions of individual TFVA's (\%) (Table 10) showed that biological treatments significantly $(P<0.05)$ increased molar percentage of acetic, propionic and butyric compared with control and untreated SBP rations. Also, R5 exhibited significantly $(P<0.05)$ the highest values, followed by R7. While, untreated SBP showed the lowest values.

The overall means of TVFA's concentration and molar proportions of acetic, propionic and butyric at the different sampling times were higher $(P<0.05) 3 \mathrm{~h}$ post- than per-feeding, then significantly $(P<0.05)$ decreased $6 \mathrm{~h}$ post-feeding.

Acetic to propionic ratio showed significant decrease $(P<0.01)$ in biological treatments as compared to untreated SBP and control rations, being the highest in R2, followed by $\mathrm{R} 2$, and nearly similar in all biological treatments. Overall mean of acetic/propionic ratio showed the same trend of TVFA's at different sampling times. The present data indicated an increase in propionate production and low acetic/propionic ratio which means an increase in propionate production. Such increase is favorable in animal growth since propionate plays a very important role as a major precursor of hepatic gluconeogensis. 
Hend, A. Aziz 
J.Animal and Poultry Prod., Mansoura Univ., Vol. 5 (12), December, 2014 
Total nitrogen, true protein nitrogen, non-protein nitrogen, ammonia nitrogen and microbial protein concentrations:

Data in Table (11) showed that biological treatments significantly $(P<0.05)$ increased $(P<0.05)$ total nitrogen $(T N)$, true protein $(T P)$, nonprotein nitrogen (NPN), ammonia nitrogen $\left(\mathrm{NH}_{3}-\mathrm{N}\right)$ and microbial protein (MP) concentrations in RL as compared to control and untreated SBP rations. Rams fed R5 showed significantly $(P<0.05)$ the highest values of $T N$, TP, $\mathrm{NPN}, \mathrm{NH}_{3}-\mathrm{N}$ and MP concentrations, followed by R7, while the lowest one was for R2.

The overall means of all values showed an increase $(P<0.01) 3 \mathrm{~h}$ postfeeding, then decreased $(P<0.01) 6 \mathrm{~h}$ post-feeding. The increment in microbial protein by biological treatments is may be due to the improvement in microbial population. Microbial protein plays an important role as it analyzed by animal enzymes in the abomasum and small intestine to produce free amino acids which absorbed from the small intestine and used by the host animal (Aziz, 2009).

The present results of rumen parameters are in agreement with those obtained by Khorshed (2000); Gado et al. (2006); Abo-Eid et al. (2007) and Aziz (2009), who reported that biological treatment for by- products improved ruminal $\mathrm{pH}$ value, and concentration of TVFA's, NPN and $\mathrm{NH}_{3}-\mathrm{N}$. They also found that ruminal parameters were at minimum before feeding and increased to maximum level at 3 and decreased $6 \mathrm{~h}$ after feeding. Moreover, Chikunya et al. (1996) concluded that the microbial protein production was improved on rations containing SBP.

\section{Ruminal microorganisms:}

Data in Table (12) represented the identification of ruminal ciliate protozoa species and their density in the rumen liquor and total bacteria and cellulolytic bacteria numbers during all different sampling times. Seven genera with 13 species and 7 sub-species of ruminal protozoa were identified in ruminal liquor of sheep in this study.

These generas (genus) are Entodinum spp. [E. simplex, E. caudatum, E. bursa, E. minimum and E. triacum], Dasytrachia rummantium, Isotrchia spp. [I. intestinalis and I. prostoma], Epidiniume caudatum, Diplodinum anisacanthum, Polyolastron multivesiculatum and Ophryoscolox spp. [O. caudatus and O. purkynjei].

Results clearly showed that biological treatments significantly increased $(P<0.01)$ total and differential numbers of ruminal ciliate protozoa $\left(\times 10^{4} \mathrm{cell} / \mathrm{ml}\right.$ rumen liquor) more than control and untreated SBP rations. It is clear that R5 had the highest $(P<0.01)$ values of total protozoa count (Entodinum, Isotrchia, Dasytrachia and Epidinium spps.), followed by R7. Meanwhile, Polyolastron, Ophryoscolox and Diplodinum spps. counts were higher in R7 more than other treatments, followed by R5. Total protozoa count range was $6.22-7.25 \times 10^{4} \mathrm{cell} / \mathrm{ml} \mathrm{RL}$. It seems that the highest presence among all species was for Entodinum spps. as it ranged between 4.93-5.83 $\times 10^{4} \mathrm{cell} / \mathrm{ml} \mathrm{RL}$, followed by Dasytrachia and Polyolastron spps. Comparison among different sampling times indicated that protozoa count showed a decrease $(P<0.01)$ at $3 \mathrm{~h}$ post-feeding then it showed the highest $(P<0.01)$ numbers 6 $h$ post feeding. 
J.Animal and Poultry Prod., Mansoura Univ., Vol. 5 (12), December, 2014

11 
Hend, A. Aziz 
J.Animal and Poultry Prod., Mansoura Univ., Vol. 5 (12), December, 2014 
The values obtained in this study considered as normal level in rumen (Hungate, 1966). The present results are in agreement with Ivan et al. (2000), who found that Entodinium was the most detrimental of ciliate protozoa species. Also, Aziz (2009) found that biological treatment of poor quality roughage increased total and differential numbers of ruminal protozoa. While, Mohsen et al. (1999) found no effect of feeding rations containing 25 or $50 \%$ SBP on protozoal count in RL of sheep.

As for total bacteria $\left(\times 10^{8} \mathrm{cell} / \mathrm{ml}\right.$ rumen) and cellulolytic bacteria $\left(x 10^{6}\right.$ cell $/ \mathrm{ml}$ rumen) numbers, biological treatments increased $(P<0.01)$ their numbers more than control and untreated SBP rations. It seems that SBP treated with Cellulomonas cellulasea (R6) and C. cellulasea $+S$. cerevisiae (R7) had the highest $(P<0.01)$ number of bacteria and cellulolytic bacteria, as $\mathrm{R} 7$ came in the first class, followed by R6 and then R5 ( $T$. viride $+\mathrm{S}$. cerevisiae) came in the third class.

\section{Blood parameters:}

Results shown in Table (13) revealed that biological treatments significantly increased $(P<0.01)$ concentration of total proteins and albumin values $(\mathrm{g} / \mathrm{dl})$ as compared to control and untreated SBP, being the highest in serum of rams fed R5, followed by R7. Meanwhile the lowest values were found for those fed R2. On the other hand, globulin concentration decreased $(P<0.05)$ in rams fed R5 and R7, and increased $(P<0.05)$ in R3, R4 and R6 as compared to control and untreated SBP rations.

Such results were reflected in the highest $(P<0.05)$ albumin/globulin ratio only for $\mathrm{R} 5$ and $\mathrm{R} 7$ as compared to other rations. In addition, biological treatments, in particular for $R 5$ decreased $(P<0.01)$ serum urea values $\mathrm{mg} / \mathrm{dl}$ as compared to untreated SBP and control rations.

It is of interest to note that biological treatments of SBP only in R5 and R7 significantly $(P<0.05)$ decreased activity of serum AST and ALT as compared to untreated SBP in R2.

As affected by sampling time all blood parameters $4 \mathrm{~h}$ post-feeding was higher $(P<0.01)$ than pre-feeding values.

These results showed that biological treatments of SBP did not cause any lesions in liver and kidney functions.

Similar results were obtained with biological treatments by Kholif et al. (2001) and Aziz (2009), who reported that biological treatment increased total proteins albumin and globulin concentrations, and decreased urea concentration, AST and ALT activities in blood serum. 
J.Animal and Poultry Prod., Mansoura Univ., Vol. 5 (12), December, 2014

13

669 


\section{CONCLUSION}

It could be concluded that, inclusion of dried sugar beet pulp untreated or treated with biological treatments to replace a part of $30 \%$ of common concentrate feed mixture had remarkable improved influence on chemical composition and fiber fraction. Biological treatments decreased feed intake more than control and untreated sugar beet pulp groups which may be decreased feed costs, in the same time increased all nutrients digestibility coefficients. Also, improved nitrogen balance, increased ruminal TVFA's, total nitrogen, true protein and microbial protein, all these improvements will enhance animal performance.

\section{REFERENCES}

Abedo, A.A.; M.A. El-Ashry, A.Y. El-Badawi, F.I.S. Helal and M. Fadel (2005). Effect of feeding biologically treated sugar beet pulp on growth performance of sheep. Egyptian J. Nutrition and Feeds. 8: 579-590.

Abo-Eid, H.A.; M.A. El-Ashry; M.M. Khorshed and M.F. El-Sayes (2007). Effect of biological treatments of some crop residues on their nutritive values:1- Effect of biological treatments on recovery rate, chemical composition and in situ disappearance. Egyptian J. Nutrition and feeds, 10 (2) (Special Issue): 493508.

Allam, M. Sabbah; T.M. Al-Bedawi; Hanaa H. El-Amary and Shereen H. Mohamed (2006). Improving sugar beer pulp through biological treatment and its use in sheep ration. Egyptian J. Nutrition and Feeds.9(2): 235-247.

A.O.A.C. (1990). Official Methods of Analysis of the Association of Official Agricultural Chemists. Washington. D.C., USA.

Aziz, Hend A. (2009). Effect of feeding olive tree pruning by-products in Sinai on sheep performance. Ph. D. Thesis, Fac. of Agric., Ain Shams Univ.

Bryant, M.P. (1972). Commentary on the Hugate technique for culture of anaerobic bacteria. Am. J. Clin. Nutr., 25:1324.

Chikunya, S., C.J. Newbold, L.Rode, X.B. Chen and R.J. Wallace (1996). Influence of dietary rumen degradable protein on bacterial growth in the rumen of sheep receiving different energy sources. A.nim. Feed Sci. and Technol., 63: 1-4, 333.

Colombatto, D; F.L. Mould; M.K. Bhat; D.P. Morgavi; K.A. Beauchemin and E. Owen (2003). Influence of fibrolytic enzymes on the hydrolysis and fermentation of pure cellulose and xylan by mixed ruminalmicroganisms in vitro. J. Anim. Sci., 81:1040-1050.

Dehority, B.A. (1993). Laboratory Manual for classification and Morphology of rumen ciliate protozoa. CRC. Press Inc., Florida.

Deraz. T.A. and H. Ismail (2001). Cotton stalks treated with white rot fungi for feeding sheep, Egyptian J. Nutrition and feeds, 4(Special Issue): 423-434.

Duncan, D.B. (1955). Multiple range and multiple F-test. Biometrics. 11:1-42.

El-Ashry, M.A.; H.M. El-Sayed; M. Fadel; H.M. Metwally and M.M. Khorshed (2002). Effect of chemical and biological treatmentsd of some crop residues on their nutritive value 2- effect of biological treatments on chemical composition and in vitro disappearance. Egyptian J. Nutrition and feeds, (1): 43-54.

El-Ashry, M.A.; A.M. Kholif; M. Fadel; H.A. El-Alamy; H.M. El-Sayed and S.M. Kholif (2003). Effect of biological treatments on chemical composition and in vitro and in vivo digestibilities of poor quality roughages. Egyptian J. Nutr. and Feeds, 6:113-126.

El-Badawi, A.Y.; A.A. Abedo; M.A. El-Ashry; F.I.S. Helal and M.H.M. Yacout (2007). Microbial protein enrichment of sugar beet pulp by aerobic fermentation: 2Reflection of tow dietary replacement levels of SBP or Fungal treated SBP on ruminal degradation Kinetics, rumen fermentation and some Hematological parameters of sheep. Egyptian J. Nutrition and feeds, 10 (2)(Special Issue): 569-584. 
Fouad, R.T. (1991). Effect of some mechanical treatments and feed additives on the nutritional value of corn stalks. M. Sc. Thesis, Fac. of Aric., Al-Azhar Univ.

Gado, H.M. and R.I. Abd El-Galil (2009). Evaluation differences of some ruminal bacteria by in vitro dry matter, cellulose and hemicellulose disappearance rate and extent of bagasse. Egyptian J. Nutrition and Feeds, 12 (3):359-372.

Gado, H.; A.N. Sohair; K.M. Bahira and A.A. Mahrous (2006). Effect of biological treatments on the nutritive value of rice straw. Egyptian J. Nutrition and Feeds, 9(2): 207-219.

Haaksma, J. (1982). Feeding value of pressed beet pulp compared to other fodders. Proc. Int. Inst. Sugar beet Research, $45^{\text {th }}$ winter Congress, USA.

Hassan, A.A.; M.H.M. Yacout; M.KK. Mohsen; M.I. Bassiouni and M. Abd El-All (2005). Banana wastes (Musa acuminate L.) silage treated biologically or with urea for dairy cows feeding. Egyptian J. Nutr. and Feeds, 8(1) Special Issue:49-61.

Hungate, R.E. (1966). The Rumen and its Microbes. Academic Press Inc., New York and London.

Israilides, C.J.; D. Iconomou; K. Kandylis and P. Nikokyris (1994). Fermentability of sugar beet pulp and its acceptability in mice. Bioresour Technology, 47: 97.

Ivan, M.; L. Neill; R. Forster; R. Alimon; T.L.M. Rode, and T. Entz (2000). Effects of Isotricha, Dasytricha, Entodinium, and total Fauna on Ruminal fermentation and duodenal flow in wethers fed different diets. J. Dairy Sci. 83: 776-787.

Khampa, S.; P. chaowwarat; R.Singhalert; R. Pilajun and M. Wanapat (2009). Supplementation of yeast fermented Cassava chip as a replacement concentrate on rumen fermentation efficiency amd digestibility of nutrients in heifer. J. Anim. and Vet. Advances. 8(6):1091-1095.

Kholif, A.M.; H.A. El-Alamy; M.A. El-Ashry; H.M. El-Sayed, M. Fadel and S.M. Kolifi (2001). Biological treatments of Banana wastes for location Goats Feeding. Egyptian J. Nutrition and feeds, (special issue): 437-438.

Kholif, A.M.; M.A. El-Ashry; H.A. El-Alamy; H.M. El-Sayed; M. Fadel; and S.M. Kholif (2005). Biological treatments of banana wastes for feeding lactating goats. Egyptian J. Nutrition and feeds. (2): 149-162.

Khorshed, M.M. (2000). Different treatments for improving nutritional quality of some crop residues used in ruminant nutrition. Thesis $\mathrm{Ph}$. D. degree. Faculty of Agriculture. Ain Shams University.

Kjaergaard, L. (1984). Examples of biotechnological utilization of beet pulp and bagasse. Sugar Technol. Rev., 10:183.

Mahrous, A.A and Faten, A. Abou Ammou ( 2005). Effect of biological treatments for rice straw on the productive performance of sheep. Egyptian J. Nutrition and Feeds. 8(1) (Special Issue): 529-540.

Mann, S.O. (1968). An improved method for determining cellulolytic activity in anaerobic bacteria. J. Appl. Bacteriol., 31:241.

Mansfield, H.R.; M.D. Stern and D.E. Otterby (1994). Effects of beet pulp and animal by-products on milk yield and in vitro fermentation by rumen microorganisms. J. Dairy Sci., 77:205.

Mohsen, M.K.; M.F. Ali and M.I. Bassiouni (1999). The effect of partial replacing concentrate mixture by dried sugar beet pulp on performance of growing Angora goats. Egyptian J. Nutr. and Feeds, 2 (Special Issue), 309.

Molina, A.E.; A.I.G. Martin and J.F. Aguilera (2000). Comparative study of nutrient digestibility, Kinetics of degradation and passage and rumen fermentation pattern in goats and sheep offered good quality diets. J. of Livestock Prod. Sci., 64:2-3, 215.

Nigam, P. (1994). process selection for protein enrichment; fermentation of the sugar industry by-products molasses and sugar beet pulp. Process Biochemistry.29:337. 
Norris, K.H. (1976). Predicting forage quality by infrared reflectance spectroscopy. J. Anim. Sci., 43:889.

Ogimoto, K. and S. Imai (1981). Atlas of Rumen Microbiology. Japan Scientific Societies Press, Tokyo.

Rode, L.M.; W.Z. Yang and K.A. Beauchemin (1999). Fibrolytic enzyme supplements for dairy cows in early lactation. J. Dairy Sci., 82:2121-2126.

SAS (2000). Statistical Analysis Systems Institute Inc., Release 8.1, Cary, NC., USA.

SMA (2011). Statistics of Ministry of Agriculture, Egyptian. Economic Affairs, Sector of Agricultural statistics, 2011.

Subhash C.; M.R. Reddy and G.V.N. Reddy (1991). Effect of fungal treatment of paddy straw on nutrient utilization in complete diets for sheep. Indian Journal of Animal Sciences, 61 (12): 1330-1334.

Terry, R.A.; J.M.A. Tilley and G.E. Outen (1969). Effect of pH on cellulose digestion under in vitro Conditions. J. Sci. F. Agric., 20:317.

Van Soest, P.J.; J.B. Robertson and B.A. Lewis (1991). Methods for dietary fiber, neutral detergent fiber and non-starch polysaccharides on animal nutrition. J. Dairy, Sci., 74,3583.

Warner, A.C.J. (1964). Production of volatile fatty acids in the rumen methods of measurements. Nutr. Abst. \& Rev., 34:339.

Yang W.Z.; K.A. Beauchemin and L.M. Rode (1999). Effects of anenzyme feed additive on extent of digestion and milkproduction of lactating dairy cows. J. Dairy., 82:391-403.

Zadrazil, F. (1984). Microbial conversion of lignocellulose into feed. In: F. Sundstol and E. Owen: Straw and Other Fibrous By Products as feed pup. Elsevier Amsterdam, Pp.276-291.

تـأثير تفل بنجـر السـكر المعامـل بيولوجيـاً على التحليـل الكميـائى و اختفـاء المـواد الغذائيـة والهضـم وتخمـرات وميكروبـات الكرش و بعض مكونـات الـدم فى الأغنـام

قسم تغذية الحيوان - مركز بحوث الصدراء أنداء - القاهره - جمهورية مصر العربيه

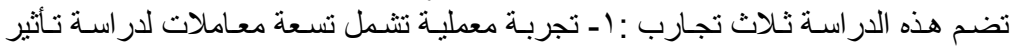

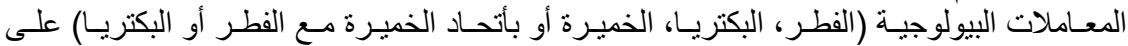

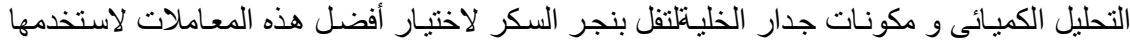

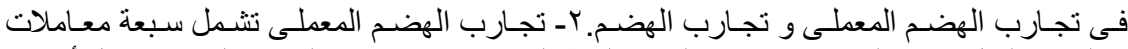

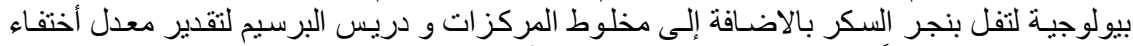

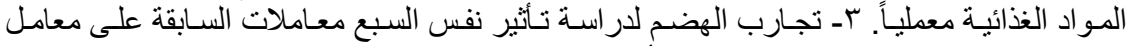

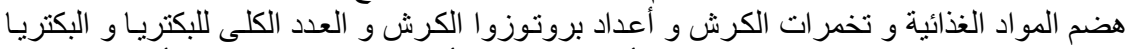

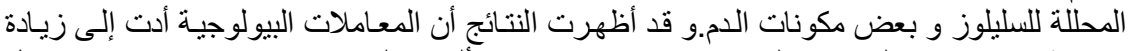

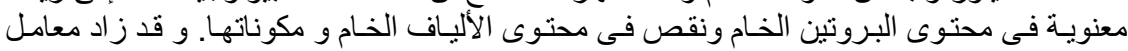

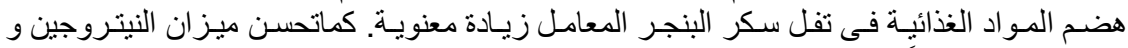

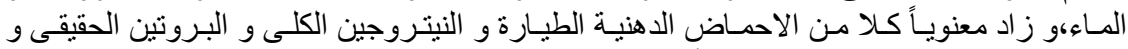

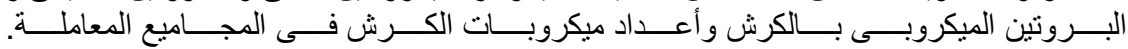


J.Animal and Poultry Prod., Mansoura Univ., Vol. 5 (12): 649 -672, 2014

Table (7): Effect of treatments on nutrient digestibility and nutritive value of the experimental rations.

\begin{tabular}{|c|c|c|c|c|c|c|c|c|}
\hline Item & R1 & R2 & R3 & R4 & R5 & R6 & R7 & \pm MSE \\
\hline Number of animals & 4 & 4 & 4 & 4 & 4 & 4 & 4 & - \\
\hline Live body weight & 33.18 & 33.06 & 33.43 & 33.52 & 33.31 & 33.01 & 33.33 & 1.36 \\
\hline Fee intake $\mathrm{g} / \mathrm{h} / \mathrm{d}$ & $1321.36^{a}$ & $1132.28^{b}$ & $1052.94^{c}$ & $1009.01^{c}$ & $917.76^{d}$ & $1076.28^{\mathrm{bc}}$ & $1034.51^{\mathrm{c}}$ & 21.28 \\
\hline$\frac{D \text { DM }}{D M}$ & $79.50^{\mathrm{b}}$ & $77.54^{\mathrm{c}}$ & $78.72^{\mathrm{bc}}$ & $78.82^{\mathrm{bc}}$ & $85.29^{a}$ & $79.72^{b}$ & $83.90^{a}$ & 0.602 \\
\hline OM & $80.10^{c}$ & $78.89^{d}$ & $79.77^{\mathrm{cd}}$ & $79.92^{c}$ & $86.23^{a}$ & $80.70^{c}$ & $84.79^{b}$ & 0.312 \\
\hline EE & $87.34^{\mathrm{bc}}$ & $86.34^{c}$ & $86.88^{\mathrm{bc}}$ & $87.19^{b c}$ & $90.58^{a}$ & $85.48^{c}$ & $88.60^{b}$ & 0.648 \\
\hline $\mathrm{CP}$ & $83.47^{d}$ & $78.37^{e}$ & $89.33^{b c}$ & $88.92^{\mathrm{c}}$ & $92.13^{a}$ & $89.05^{c}$ & $91.25^{\mathrm{ab}}$ & 0.647 \\
\hline CF & $60.85^{d}$ & $66.10^{c}$ & $67.15^{\mathrm{c}}$ & $66.83^{c}$ & $75.91^{a}$ & $70.69^{b}$ & $75.25^{a}$ & 0.515 \\
\hline NFE & $82.74^{b}$ & $81.41^{b c}$ & $80.11^{c}$ & $80.18^{c}$ & $86.06^{a}$ & $80.76^{c}$ & $85.52^{\mathrm{a}}$ & 0.503 \\
\hline Fiber fractions: & & & & & & & & \\
\hline NDF & $58.06^{c}$ & $72.41^{b}$ & $76.56^{b}$ & $77.32^{b}$ & $82.43^{a}$ & $77.37^{b}$ & $82.48^{a}$ & 0.653 \\
\hline ADF & $47.41^{\mathrm{e}}$ & $63.49^{c}$ & $61.03^{d}$ & $62.51^{\mathrm{c}}$ & $74.07^{a}$ & $65.50^{b}$ & $75.06^{a}$ & 0.460 \\
\hline ADL & $54.01^{\mathrm{d}}$ & $47.59^{f}$ & $46.56^{f}$ & $49.74^{\mathrm{e}}$ & $69.30^{\mathrm{b}}$ & $56.17^{\mathrm{c}}$ & $71.92^{\mathrm{a}}$ & 0.665 \\
\hline Cellulose & $52.17^{d}$ & $69.80 c^{c}$ & $69.94^{c}$ & $70.53^{c}$ & $79.29^{a}$ & $72.45^{b}$ & $80.32^{a}$ & 0.470 \\
\hline Hemicellulose & $65.58^{d}$ & $78.72^{c}$ & $89.26^{\mathrm{ab}}$ & $90.99^{a}$ & $88.74^{\mathrm{ab}}$ & $87.54^{b}$ & $87.40^{b}$ & 0.769 \\
\hline Nutritive value: & & & & & & & & \\
\hline TDN g/h/d & $1021.29^{a}$ & $827.42^{b}$ & $777.21^{b c}$ & $749.56^{c}$ & $716.63^{c}$ & $810.95^{b}$ & $810.59^{b}$ & 605.08 \\
\hline TDN $\mathrm{g} / \mathrm{kg}$ BW & $30.79^{a}$ & $24.99^{b}$ & $23.44^{\mathrm{bc}}$ & $22.61^{\mathrm{c}}$ & $21.67^{c}$ & $24.69^{b}$ & $24.44^{\mathrm{b}}$ & 17.19 \\
\hline TDN g/kg BW 0.75 & $73.89^{a}$ & $59.93^{b}$ & $56.22^{\mathrm{bc}}$ & $54.20^{c}$ & $51.93^{d}$ & $59.08^{b}$ & $58.63^{b}$ & 41.87 \\
\hline TDN\% of DMI & $77.30^{\mathrm{ab}}$ & $73.03^{d}$ & $73.97^{\mathrm{c}}$ & $74.29^{b c}$ & $78.12^{\mathrm{a}}$ & $75.70^{\mathrm{b}}$ & $78.49^{a}$ & 66.48 \\
\hline DCP g/h/d & $138.02^{d}$ & $89.05^{\mathrm{e}}$ & $156.50^{\mathrm{ab}}$ & $146.40^{\mathrm{cd}}$ & $148.04^{\mathrm{bc}}$ & $155.81^{a b}$ & $162.41^{a}$ & 2.95 \\
\hline DCP g/kg BW & $4.16^{b}$ & $2.69^{\mathrm{c}}$ & $4.72^{a b}$ & $4.41^{\mathrm{ab}}$ & $4.47^{\mathrm{ab}}$ & $4.74^{\mathrm{ab}}$ & $4.89^{\mathrm{a}}$ & 0.206 \\
\hline DCP g/kg BW 0.75 & $9.98^{b}$ & $6.45^{\mathrm{c}}$ & $11.32^{\mathrm{a}}$ & $10.58^{\mathrm{ab}}$ & $10.73^{a b}$ & $11.35^{\mathrm{a}}$ & $11.75^{\mathrm{a}}$ & 0.405 \\
\hline DCP \% of DMI & $83.63^{b}$ & $72.51^{\mathrm{C}}$ & $89.28^{\mathrm{ab}}$ & $88.63^{a b}$ & $92.71^{a}$ & $88.84^{\mathrm{ab}}$ & $91.43^{a b}$ & 2.39 \\
\hline Metabolic energy & 3.69 & 2.99 & 2.81 & 2.71 & 2.59 & 2.93 & 2.93 & 2.19 \\
\hline
\end{tabular}

Means with different litters with each row are significantly different $(P<0.05)$. 
Table (8): Nitrogen balance of sheep fed experimental treatments.

\begin{tabular}{|c|c|c|c|c|c|c|c|c|c|}
\hline Balnce & Item & R1 & R2 & R3 & R4 & R5 & R6 & R7 & \pm MSE \\
\hline \multirow{3}{*}{ Nitrogen intake } & $g / h / d$ & $26.41^{\mathrm{c}}$ & $19.65^{e}$ & $28.04^{b}$ & $26.43^{c}$ & $25.55^{d}$ & $28.06^{b}$ & $28.42^{a}$ & 0.000 \\
\hline & $\mathrm{g} / \mathrm{kg} \mathrm{BW}$ & $0.797^{a}$ & $0.595^{\mathrm{b}}$ & $0.845^{a}$ & $0.797^{a}$ & $0.772^{a}$ & $0.855^{a}$ & $0.857^{a}$ & 0.031 \\
\hline & $\mathrm{g} / \mathrm{kg} \mathrm{BW} 0.75$ & $1.91^{\mathrm{ab}}$ & $1.43^{c}$ & $2.02^{a b}$ & $1.91^{\mathrm{ab}}$ & $1.85^{b}$ & $2.04^{a}$ & $2.05^{\mathrm{a}}$ & 0.056 \\
\hline \multirow{4}{*}{ Digested nitrogen } & $\mathrm{g} / \mathrm{h} / \mathrm{d}$ & $22.08^{c}$ & $14.24^{\mathrm{d}}$ & $25.03^{a b}$ & $23.42^{\mathrm{bc}}$ & $23.68^{b}$ & $24.62^{\mathrm{ab}}$ & $25.73^{a}$ & 0.516 \\
\hline & $\mathrm{g} / \mathrm{kg} \mathrm{BW}$ & $0.665^{b}$ & $0.430^{c}$ & $0.755^{a b}$ & $0.706^{a b}$ & $0.716^{\mathrm{ab}}$ & $0.750^{\mathrm{ab}}$ & $0.776^{a}$ & 0.033 \\
\hline & $\mathrm{g} / \mathrm{kg} \mathrm{BW} 0.75$ & $1.59^{b}$ & $1.03^{c}$ & $1.81^{\mathrm{ab}}$ & $1.69^{a b}$ & $1.71^{\mathrm{ab}}$ & $1.79^{a b}$ & $1.86^{\mathrm{a}}$ & 0.066 \\
\hline & $\%$ of $\mathrm{N}$ intake & $83.63^{b}$ & $72.51^{\mathrm{c}}$ & $89.28^{a b}$ & $88.64^{\mathrm{ab}}$ & $92.71^{a}$ & $87.74^{\mathrm{ab}}$ & $90.54^{a b}$ & 2.51 \\
\hline \multirow{4}{*}{ Fecal nitrogen } & $\mathrm{g} / \mathrm{h} / \mathrm{d}$ & $4.32^{a}$ & $4.42^{a}$ & $3.45^{b}$ & $3.64^{b}$ & $2.86^{c}$ & $3.77^{\mathrm{b}}$ & $3.71^{b}$ & 0.102 \\
\hline & $\mathrm{g} / \mathrm{kg} \mathrm{BW}$ & $0.130^{a}$ & $0.132^{a}$ & $0.105^{b}$ & $0.110^{\mathrm{b}}$ & $0.087^{c}$ & $0.115^{\mathrm{b}}$ & $0.110^{\mathrm{b}}$ & 0.004 \\
\hline & $\mathrm{g} / \mathrm{kg} \mathrm{BW}^{0.75}$ & $0.310^{a}$ & $0.320^{a}$ & $0.250^{\mathrm{b}}$ & $0.262^{\mathrm{b}}$ & $0.205^{b}$ & $0.272^{c}$ & $0.267^{\mathrm{b}}$ & 0.010 \\
\hline & $\%$ of $\mathrm{N}$ intake & $16.36^{b}$ & $22.50^{a}$ & $12.30^{\text {de }}$ & $13.77^{c}$ & $11.22^{\mathrm{e}}$ & $13.45^{\mathrm{cd}}$ & $13.05^{\mathrm{cd}}$ & 0.405 \\
\hline \multirow{4}{*}{ Urinary nitrogen } & $\mathrm{g} / \mathrm{h} / \mathrm{d}$ & $6.82^{a}$ & $6.12^{b}$ & $5.35^{c}$ & $5.21^{c}$ & $4.15^{d}$ & $5.33^{c}$ & $4.51^{d}$ & 0.155 \\
\hline & $\mathrm{g} / \mathrm{kg} \mathrm{BW}$ & $0.207^{a}$ & $0.185^{b}$ & $0.162^{c}$ & $0.160^{c}$ & $0.125^{\mathrm{d}}$ & $0.165^{\mathrm{c}}$ & $0.135^{\mathrm{d}}$ & 0.006 \\
\hline & $\mathrm{g} / \mathrm{kg} \mathrm{BW}^{0.75}$ & $0.500^{\mathrm{a}}$ & $0.445^{\mathrm{ab}}$ & $0.385^{\mathrm{bc}}$ & $0.360^{\mathrm{bcd}}$ & $0.290^{\mathrm{d}}$ & $0.415^{\mathrm{ab}}$ & $0.350^{\mathrm{cd}}$ & 0.024 \\
\hline & $\%$ of $\mathrm{N}$ intake & $26.30^{\mathrm{b}}$ & $30.54^{a}$ & $19.93^{c}$ & $19.58^{c}$ & $15.87^{d}$ & $20.03^{c}$ & $17.06^{\mathrm{d}}$ & 0.404 \\
\hline \multirow{4}{*}{ Total N excretion } & $\mathrm{g} / \mathrm{h} / \mathrm{d}$ & $11.20^{\mathrm{a}}$ & $10.34^{b}$ & $8.98^{c d}$ & $8.82^{\mathrm{cd}}$ & $6.99^{e}$ & $9.33^{c}$ & $8.71^{d}$ & 0.155 \\
\hline & $\mathrm{g} / \mathrm{kg} \mathrm{BW}$ & $0.335^{a}$ & $0.320^{\mathrm{ab}}$ & $0.255^{\mathrm{bc}}$ & $0.260^{\mathrm{abc}}$ & $0.210^{c}$ & $0.285^{\mathrm{abc}}$ & $0.260^{\mathrm{abc}}$ & 0.021 \\
\hline & $\mathrm{g} / \mathrm{kg} \mathrm{BW} 0.75$ & $0.810^{a}$ & $0.760^{\mathrm{ab}}$ & $0.620^{\mathrm{bc}}$ & $0.620^{b c}$ & $0.505^{c}$ & $0.685^{\mathrm{ab}}$ & $0.620^{\mathrm{bc}}$ & 0.039 \\
\hline & $\%$ of $\mathrm{N}$ intake & $42.43^{b}$ & $52.64^{a}$ & $32.03^{\mathrm{cd}}$ & $33.38^{c}$ & $27.38^{e}$ & $33.27^{c}$ & $30.65^{d}$ & 0.614 \\
\hline \multirow{5}{*}{ Nitrogen balance } & $\mathrm{g} / \mathrm{h} / \mathrm{d}$ & $15.20^{d}$ & $9.30^{\mathrm{e}}$ & $19.06^{b}$ & $17.60^{c}$ & $18.55^{b}$ & $18.72^{\mathrm{b}}$ & $19.71^{\mathrm{a}}$ & 0.157 \\
\hline & $\mathrm{g} / \mathrm{kg} \mathrm{BW}$ & $0.455^{a}$ & $0.285^{\mathrm{b}}$ & $0.540^{a}$ & $0.510^{a}$ & $0.560^{a}$ & $0.570^{a}$ & $0.585^{a}$ & 0.041 \\
\hline & $\mathrm{g} / \mathrm{kg} \mathrm{BW} W^{0.75}$ & $1.10^{\mathrm{b}}$ & $0.685^{c}$ & $1.31^{\mathrm{ab}}$ & $1.23^{a b}$ & $1.34^{\mathrm{ab}}$ & $1.37^{a b}$ & $1.40^{\mathrm{a}}$ & 0.076 \\
\hline & $\%$ of $\mathrm{N}$ intake & $57.57^{d}$ & $47.36^{e}$ & $67.96^{b c}$ & $66.61^{c}$ & $72.62^{a}$ & $66.72^{c}$ & $69.34^{b}$ & 0.614 \\
\hline & $\%$ of digested $\mathrm{N}$ & $69.12^{c}$ & $65.70^{d}$ & $76.86^{\mathrm{ab}}$ & $75.03^{\mathrm{ab}}$ & $78.23^{a}$ & $77.02^{\mathrm{ab}}$ & $78.46^{a}$ & 2.72 \\
\hline
\end{tabular}

Means with different litters with each row are significantly different $(\mathrm{P}<0.05)$. 
Table (9): Water balance for sheep fed experimental treatments:

\begin{tabular}{|c|c|c|c|c|c|c|c|c|c|c|}
\hline Balance & \multicolumn{2}{|c|}{ Item } & R1 & R2 & R3 & R4 & R5 & R6 & R7 & \pm MSE \\
\hline \multirow{4}{*}{$\begin{array}{l}\text { Water } \\
\text { intake }\end{array}$} & Free & $\begin{array}{l}\mathrm{ml} / \mathrm{h} / \mathrm{d} \\
\mathrm{ml} / \mathrm{Kg} \mathrm{W} \mathrm{W}^{0.82}\end{array}$ & $\begin{array}{c}3640.00 \\
206.00\end{array}$ & $\begin{array}{c}3625.00 \\
205.83\end{array}$ & $\begin{array}{c}3617.50 \\
204.62\end{array}$ & $\begin{array}{c}3622.50 \\
204.33\end{array}$ & $\begin{array}{c}3612.50 \\
205.27\end{array}$ & $\begin{array}{c}3620.00 \\
206.57\end{array}$ & $\begin{array}{c}3612.50 \\
203.80\end{array}$ & \begin{tabular}{|c|}
185.28 \\
10.37
\end{tabular} \\
\hline & Combined & $\begin{array}{l}\mathrm{ml} / \mathrm{h} / \mathrm{d} \\
\mathrm{ml} / \mathrm{Kg} \mathrm{W}^{0.82}\end{array}$ & $\begin{array}{l}81.92^{b} \\
4.63^{b}\end{array}$ & $\begin{array}{c}123.42^{\mathrm{a}} \\
7.01^{\mathrm{a}}\end{array}$ & $\begin{array}{l}75.81^{c} \\
4.28^{\mathrm{cd}}\end{array}$ & $\begin{array}{l}76.68^{c} \\
4.34^{\mathrm{cd}}\end{array}$ & $\begin{array}{l}58.27^{\mathrm{e}} \\
3.30^{\mathrm{e}}\end{array}$ & $\begin{array}{l}86.20^{b} \\
4.93^{b c}\end{array}$ & $\begin{array}{l}68.17^{d} \\
3.86^{d}\end{array}$ & $\begin{array}{c}1.65 \\
0.172\end{array}$ \\
\hline & Metabolic & $\begin{array}{l}\mathrm{ml} / \mathrm{h} / \mathrm{d} \\
\mathrm{ml} / \mathrm{Kg} \mathrm{W} 0.82\end{array}$ & $\begin{array}{l}704.69^{a} \\
39.90^{a}\end{array}$ & $\begin{array}{c}570.92^{b} \\
32.37^{b}\end{array}$ & $\begin{array}{c}536.27^{\mathrm{cd}} \\
30.36^{\mathrm{bc}}\end{array}$ & $\begin{array}{c}517.20^{\mathrm{de}} \\
29.27^{\mathrm{bc}}\end{array}$ & $\begin{array}{c}494.47^{\mathrm{e}} \\
28.05^{\mathrm{c}}\end{array}$ & $\begin{array}{c}559.55^{\mathrm{bc}} \\
31.93^{\mathrm{b}}\end{array}$ & $\begin{array}{c}559.30^{\mathrm{bc}} \\
31.66^{\mathrm{b}}\end{array}$ & $\begin{array}{l}10.48 \\
1.04\end{array}$ \\
\hline & Total & $\begin{array}{l}\mathrm{ml} / \mathrm{h} / \mathrm{d} \\
\mathrm{ml} / \mathrm{Kg} \mathrm{W} 0.82\end{array}$ & $\begin{array}{c}4426.62 \\
250.54\end{array}$ & $\begin{array}{c}4319.34 \\
245.22\end{array}$ & $\begin{array}{c}4229.59 \\
239.27\end{array}$ & $\begin{array}{c}4216.38 \\
237.95\end{array}$ & $\begin{array}{c}4165.24 \\
236.63\end{array}$ & $\begin{array}{c}4265.76 \\
243.44\end{array}$ & $\begin{array}{c}4239.98 \\
239.33\end{array}$ & $\begin{array}{c}186.41 \\
10.72\end{array}$ \\
\hline & Urina & $\begin{array}{l}\mathrm{ml} / \mathrm{h} / \mathrm{d} \\
\mathrm{ml} / \mathrm{Kg} \mathrm{W}^{0.82} \\
\% \text { of intake }\end{array}$ & $\begin{array}{c}528.00^{a} \\
29.98^{a} \\
11.84^{a}\end{array}$ & $\begin{array}{c}525.75^{a} \\
29.65^{a} \\
12.00^{a}\end{array}$ & $\begin{array}{c}442.50^{b} \\
25.11^{b} \\
10.46^{b}\end{array}$ & $\begin{array}{c}423.75^{b c} \\
23.99^{b c} \\
10.13^{b}\end{array}$ & $\begin{array}{c}352.50^{c} \\
19.95^{c} \\
8.38^{c}\end{array}$ & $\begin{array}{c}421.25^{b c} \\
24.03^{b c} \\
9.88^{b c}\end{array}$ & $\begin{array}{c}382.50^{c} \\
21.61^{c} \\
9.04^{b c}\end{array}$ & $\begin{array}{c}65.59 \\
3.82 \\
1.32\end{array}$ \\
\hline $\begin{array}{c}\text { Water } \\
\text { execration }\end{array}$ & $\begin{array}{l}\text { Fecal } \\
\text { Water }\end{array}$ & $\begin{array}{l}\mathrm{ml} / \mathrm{h} / \mathrm{d} \\
\mathrm{ml} / \mathrm{Kg} \mathrm{W} \mathrm{W}^{0.82} \\
\% \text { of intake }\end{array}$ & $\begin{array}{c}83.29^{a b} \\
4.71^{a b} \\
1.90^{a b}\end{array}$ & $\begin{array}{l}75.19^{a b} \\
4.27^{a b} \\
1.74^{a b}\end{array}$ & $\begin{array}{c}111.97^{a} \\
6.25^{a} \\
2.68^{a}\end{array}$ & $\begin{array}{l}79.29^{a b} \\
4.44^{a b} \\
1.92^{a b}\end{array}$ & $\begin{array}{l}56.32^{\mathrm{b}} \\
3.15^{\mathrm{b}} \\
1.35^{\mathrm{b}}\end{array}$ & $\begin{array}{c}65.67^{b} \\
3.72^{b} \\
1.53^{b}\end{array}$ & $\begin{array}{c}83.90^{\mathrm{ab}} \\
4.68^{\mathrm{ab}} \\
1.95^{\mathrm{ab}}\end{array}$ & $\begin{array}{l}13.60 \\
0.690 \\
0.334\end{array}$ \\
\hline & $\begin{array}{l}\text { Total water } \\
\text { execration }\end{array}$ & $\begin{array}{l}\mathrm{ml} / \mathrm{h} / \mathrm{d} \\
\mathrm{ml} / \mathrm{Kg} \mathrm{W} \mathrm{W}^{0.82} \\
\% \text { of intake }\end{array}$ & $\begin{array}{l}611.29^{a} \\
34.70^{a} \\
13.74^{a}\end{array}$ & $\begin{array}{c}600.94^{a} \\
33.93^{a} \\
13.75^{a}\end{array}$ & $\begin{array}{c}554.47^{b} \\
31.36^{c} \\
13.15^{a}\end{array}$ & $\begin{array}{c}503.04^{\mathrm{bc}} \\
28.42^{\mathrm{cd}} \\
12.05^{\mathrm{b}}\end{array}$ & $\begin{array}{c}408.82^{d} \\
23.10^{d} \\
9.73^{c}\end{array}$ & $\begin{array}{c}486.92^{\mathrm{bc}} \\
27.75^{\mathrm{cd}} \\
11.41^{\mathrm{b}}\end{array}$ & $\begin{array}{c}466.40^{c} \\
26.30^{c d} \\
10.99^{b}\end{array}$ & $\begin{array}{c}67.51 \\
3.86 \\
1.36\end{array}$ \\
\hline Wate & lance & $\begin{array}{l}\mathrm{ml} / \mathrm{h} / \mathrm{d} \\
\mathrm{ml} / \mathrm{Kg} \mathrm{W}^{0.82} \\
\% \text { of intake }\end{array}$ & $\begin{array}{c}3815.32 \\
215.84 \\
86.25\end{array}$ & $\begin{array}{c}3718.39 \\
211.28 \\
86.25\end{array}$ & $\begin{array}{c}3675.11 \\
207.91 \\
86.84\end{array}$ & $\begin{array}{c}3713.34 \\
209.52 \\
87.94\end{array}$ & $\begin{array}{c}3756.42 \\
213.53 \\
90.26\end{array}$ & $\begin{array}{c}3778.84 \\
215.69 \\
88.58\end{array}$ & $\begin{array}{c}3773.58 \\
213.03 \\
89.00\end{array}$ & $\begin{array}{c}167.44 \\
9.44 \\
1.36\end{array}$ \\
\hline
\end{tabular}

Means with different litters with each row are significantly different $(P<0.05)$. 
Table (10): Effect of treatments on ruminal pH, volatile fatty acids and molar proportion of individual VFA's.

\begin{tabular}{|c|c|c|c|c|c|c|c|c|c|c|}
\hline Item & Time, $\mathrm{h}$ & R1 & R2 & R3 & R4 & R5 & R6 & R7 & \pm MSE & Overall mean \\
\hline \multirow{2}{*}{$\begin{array}{l}\text { Ruminal } \\
\mathrm{pH} \text { value }\end{array}$} & 0 & 7.42 & 7.10 & 7.10 & 6.87 & 6.8 & 7.00 & 6.82 & 0.043 & $7.02^{\mathrm{a}} \pm 0.016$ \\
\hline & 6 & 6.72 & 6.47 & 6.25 & 6.42 & 6.20 & 6.35 & 6.37 & 0.043 & $6.40^{c} \pm 0.016$ \\
\hline TVFA's & 0 & 6.50 & 6.13 & 7.00 & 6.77 & 6.72 & 6.27 & 6.72 & 0.137 & $6.58^{c} \pm 0.051$ \\
\hline (ml equiv./100 ml & 3 & 8.12 & 7.94 & 9.35 & 9.35 & 10.56 & 9.75 & 10.17 & 0.137 & $9.32^{a} \pm 0.051$ \\
\hline R.L) & 6 & 7.17 & 6.97 & 8.37 & 8.25 & 8.36 & 8.52 & 8.34 & 0.137 & $8.00^{c} \pm 0.051$ \\
\hline \multirow{3}{*}{ Acetic } & 0 & 32.01 & 31.32 & 36.43 & 34.97 & 42.53 & 34.71 & 39.13 & 0.227 & $35.87^{c} \pm 0.086$ \\
\hline & 3 & 37.75 & 36.58 & 41.55 & 40.43 & 47.43 & 40.43 & 44.87 & 0.227 & $41.29^{a} \pm 0.086$ \\
\hline & 6 & 34.75 & 34.65 & 39.26 & 38.74 & 44.97 & 37.88 & 42.55 & 0.227 & $38.97^{b} \pm 0.086$ \\
\hline \multicolumn{2}{|c|}{ Overall mean } & $34.84^{\mathrm{e}}$ & $34.18^{f}$ & $39.08^{c}$ & $38.05^{d}$ & $44.98^{a}$ & $37.67^{d}$ & $42.18^{b}$ & 0.131 & \\
\hline \multirow[b]{2}{*}{ Propionic } & 0 & 16.15 & 15.78 & 19.36 & 20.13 & 21.46 & 18.02 & 20.43 & 0.157 & $18.76^{c} \pm 0.059$ \\
\hline & 3 & 20.35 & 17.81 & 25.41 & 21.98 & 29.5 & 22.61 & 28.49 & 0.157 & $23.74^{a} \pm 0.059$ \\
\hline Butyric & 6 & 14.85 & 14.85 & 17.99 & 17.73 & 18.33 & 15.35 & 17.10 & 0.275 & $16.60^{\mathrm{b}} \pm 0.103$ \\
\hline \multicolumn{2}{|c|}{ Overall mean } & $15.07^{d}$ & $15.01^{d}$ & $17.58^{b}$ & $16.99^{c}$ & $19.03^{a}$ & $15.14^{d}$ & $17.02^{\mathrm{c}}$ & 0.158 & \\
\hline \multirow{3}{*}{$\mathrm{A} / \mathrm{P}$ ratio } & 0 & 1.98 & 1.98 & 1.88 & 1.74 & 1.98 & 1.92 & 1.91 & 0.023 & $1.91^{\mathrm{a}} \pm 0.008$ \\
\hline & 3 & 1.85 & 2.05 & 1.63 & 1.84 & 1.60 & 1.78 & 1.57 & 0.023 & $1.76^{c} \pm 0.008$ \\
\hline & 6 & 1.91 & 2.12 & 1.73 & 1.70 & 1.75 & 1.84 & 1.73 & 0.023 & $1.83^{b} \pm 0.008$ \\
\hline \multicolumn{2}{|c|}{ Overall mean } & $1.91^{b}$ & $2.05^{a}$ & $1.74^{\mathrm{d}}$ & $1.76^{d}$ & $1.77^{d}$ & $1.85^{c}$ & $1.74^{\mathrm{d}}$ & 0.013 & \\
\hline
\end{tabular}

Means with different litters with each row and column are significantly different $(P<0.05)$ 
Table (11): Effect of treatments on ruminal pH, volatile fatty acids and molar proportion of individual VFA's (\%).

\begin{tabular}{|c|c|c|c|c|c|c|c|c|c|c|}
\hline \multirow{2}{*}{ Item } & \multirow{2}{*}{$\begin{array}{c}\text { Time } \\
\text { (h) }\end{array}$} & \multicolumn{8}{|c|}{ Experimental ration } & \multirow{2}{*}{ Overall mean } \\
\hline & & R1 & R2 & R3 & R4 & R5 & R6 & R7 & \pm MSE & \\
\hline \multirow{2}{*}{$\begin{array}{l}\text { Total nitrogen } \\
\text { (mg/dl R.L) }\end{array}$} & 0 & 95.60 & 89.78 & 109.20 & 109.30 & 126.40 & 108.84 & 124.60 & 1.562 & $109.10^{c} \pm 0.590$ \\
\hline & 3 & 117.32 & 113.22 & 128.25 & 130.55 & 149.80 & 127.44 & 143.40 & 1.562 & $130.00^{a} \pm 0.590$ \\
\hline overall mean & & $107.08^{d}$ & $102.74^{\mathrm{e}}$ & $118.90^{c}$ & $120.13^{c}$ & $138.57^{a}$ & $118.26^{c}$ & $133.80^{\mathrm{b}}$ & 0.902 & \\
\hline \multirow{2}{*}{$\begin{array}{l}\text { True protein } \\
\text { nitrogen }(\mathrm{mg} / \mathrm{dl} \\
\text { R.L) }\end{array}$} & 0 & 38.79 & 33.23 & 38.30 & 40.24 & 45.20 & 46.74 & 45.65 & 1.915 & $41.16^{b} \pm 0.724$ \\
\hline & 3 & 44.32 & 41.37 & 41.95 & 41.76 & 50.92 & 45.88 & 44.25 & 1.915 & $44.35^{\mathrm{a}} \pm 0.724$ \\
\hline \multirow{3}{*}{$\begin{array}{l}\text { NPN (mg/100 } \\
\text { ml R.L) }\end{array}$} & 0 & 56.80 & 56.55 & 70.90 & 69.05 & 81.20 & 62.10 & 78.95 & 0.915 & $67.93^{c} \pm 0.345$ \\
\hline & 3 & 73.00 & 71.85 & 86.30 & 88.79 & 98.87 & 81.56 & 99.15 & 0.915 & $85.64^{a} \pm 0.345$ \\
\hline & 6 & 68.00 & 66.85 & 80.30 & 82.79 & 93.87 & 76.96 & 92.15 & 0.915 & $80.13^{b} \pm 0.345$ \\
\hline Overall mean & & $65.93^{d}$ & $65.08^{d}$ & $79.17^{\mathrm{b}}$ & $80.21^{b}$ & $91.31^{a}$ & 73.54 & $90.08^{a}$ & 0.528 & \\
\hline $\begin{array}{l}\text { Ammonia } \\
\text { nitrogen } \\
\text { (mg/dl R.L) }\end{array}$ & 0 & 26.92 & 26.92 & 30.57 & 33.76 & 38.66 & 30.67 & 32.88 & 0.399 & $31.48^{c} \pm 0.150$ \\
\hline \multirow{2}{*}{$\begin{array}{l}\text { Microbial proteir } \\
(\mathrm{mg} / \mathrm{dl} \mathrm{RL})\end{array}$} & 3 & 105.58 & 105.58 & 112.55 & 112.61 & 129.56 & 109.88 & 115.41 & 0.326 & $113.02^{\mathrm{a}} \pm 0.123$ \\
\hline & 6 & 102.51 & 102.51 & 109.55 & 109.55 & 119.50 & 107.22 & 111.66 & 0.326 & $108.93^{b} \pm 0.123$ \\
\hline Overall mean & & $90.05^{e}$ & $89.93^{e}$ & $95.84^{c}$ & $96.17^{c}$ & $106.67^{a}$ & $94.10^{d}$ & $99.04^{b}$ & 0.188 & \\
\hline
\end{tabular}

Means with different litters with each row and column are significantly different $(P<0.05)$. 
Table (12): Effect of treatments on ruminal ciliate protozoa, total bacteria and cellulolytic bacteria numbers.

\begin{tabular}{|c|c|c|c|c|c|c|c|c|c|c|}
\hline \multirow{2}{*}{ Item } & \multirow{2}{*}{$\begin{array}{l}\text { Time } \\
\text { (h) }\end{array}$} & \multicolumn{8}{|c|}{ Experimental ration } & \multirow{2}{*}{ Overall mean } \\
\hline & & R1 & R2 & R3 & R4 & R5 & R6 & R7 & IMSE & \\
\hline \multirow{2}{*}{$\begin{array}{l}\text { Total protozo } \\
\left(\times 10^{4} \text { cell } / \mathrm{ml} \mathrm{RL}\right)\end{array}$} & 0 & 6.20 & 6.11 & 6.51 & 6.49 & 6.72 & 6.21 & 6.76 & 0.068 & $6.43^{b} \pm 0.025$ \\
\hline & 3 & 5.91 & 5.77 & 6.12 & 6.14 & 6.17 & 6.25 & 6.25 & 0.068 & $6.09^{c} \pm 0.025$ \\
\hline \multicolumn{2}{|c|}{ Overall mean } & $6.35^{\mathrm{e}}$ & $6.22^{f}$ & $6.82^{\mathrm{bc}}$ & $6.72^{c}$ & $7.25^{a}$ & $6.54^{d}$ & $6.84^{b}$ & 0.039 & \\
\hline \multirow[b]{2}{*}{ Entodinum spp. } & 0 & 4.92 & 4.81 & 5.21 & 5.18 & 5.34 & 4.91 & 5.34 & 0.061 & $5.10^{b} \pm 0.023$ \\
\hline & 3 & 4.81 & 4.70 & 5.01 & 5.01 & 5.03 & 5.11 & 5.10 & 0.061 & $4.97^{c} \pm 0.023$ \\
\hline \multirow{3}{*}{$\begin{array}{l}\text { Isotrchia } \\
\text { spp. }\end{array}$} & 0 & 0.187 & 0.186 & 0.177 & 0.181 & 0.190 & 0.179 & 0.190 & 0.005 & $0.184^{\mathrm{b}} \pm 0.001$ \\
\hline & 3 & 0.150 & 0.150 & 0.142 & 0.145 & 0.151 & 0.147 & 0.152 & 0.005 & $0.148^{c} \pm 0.001$ \\
\hline & 6 & 0.230 & 0.229 & 0.249 & 0.242 & 0.248 & 0.234 & 0.231 & 0.005 & $0.237^{a} \pm 0.001$ \\
\hline \multicolumn{2}{|c|}{ Overall mean } & $0.189^{a b}$ & $0.188^{a b}$ & $0.189^{a b}$ & $0.189^{a b}$ & $0.196^{a}$ & $0.187^{b}$ & $0.191^{a b}$ & 0.002 & \\
\hline $\begin{array}{l}\text { Dasytrachia } \\
\text { spp. }\end{array}$ & 0 & 0.364 & 0.384 & 0.404 & 0.402 & 0.412 & 0.393 & 0.412 & 0.007 & $0.396^{b} \pm 0.002$ \\
\hline \multirow[t]{2}{*}{ Epidinium spp. } & 3 & 0.116 & 0.114 & 0.120 & 0.116 & 0.122 & 0.120 & 0.120 & 0.003 & $0.118^{c} \pm 0.001$ \\
\hline & 6 & 0.162 & 0.160 & 0.188 & 0.194 & 0.197 & 0.193 & 0.219 & 0.003 & $0.188^{a} \pm 0.001$ \\
\hline \multicolumn{2}{|c|}{ Overall mean } & $0.142^{\mathrm{d}}$ & $0.139^{d}$ & $0.152^{c}$ & $0.153^{\mathrm{bc}}$ & $0.158^{a}$ & $0.155^{\mathrm{bc}}$ & $0.165^{b}$ & 0.001 & \\
\hline
\end{tabular}

Means with different litters with each row and column are significantly different $(P<0.05)$. 
Table (12): Continued

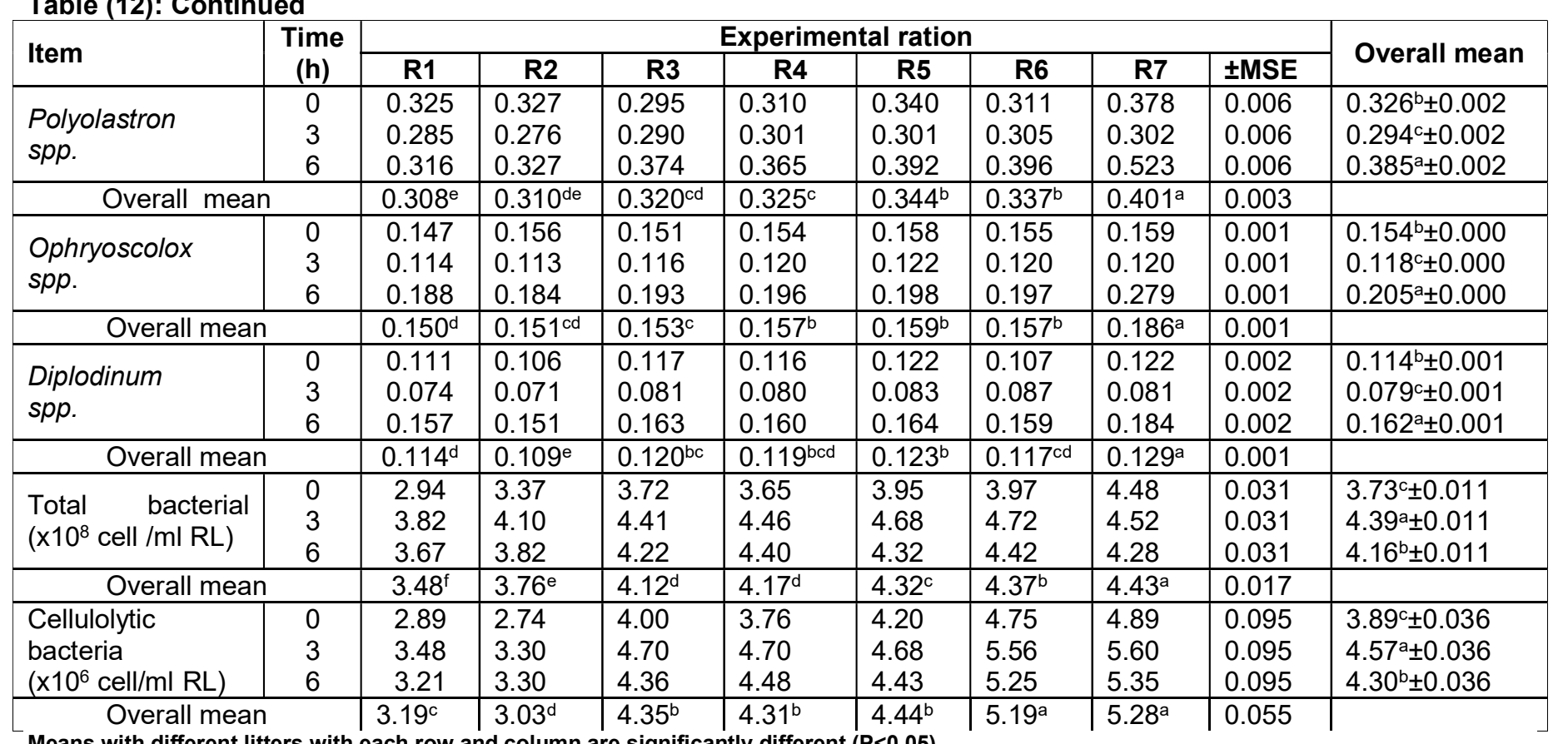

Means with different litters with each row and column are significantly different $(P<0.05)$. 
Table (13): Effect of experimental treatments on blood composition:

\begin{tabular}{|c|c|c|c|c|c|c|c|c|c|c|}
\hline \multirow{2}{*}{ Item } & \multirow{2}{*}{$\begin{array}{c}\text { Time } \\
\text { (h) }\end{array}$} & \multicolumn{8}{|c|}{ Experimental ration } & \multirow{2}{*}{ Overall mean } \\
\hline & & R1 & R2 & R3 & R4 & R5 & R6 & R7 & \pm MSE & \\
\hline$(\mathrm{g} / \mathrm{dl})$ & 4 & 8.12 & 7.50 & 8.45 & 8.43 & 9.55 & 8.23 & 9.05 & 0.083 & $8.47^{a} \pm 0.031$ \\
\hline Albumin (AL) & 0 & 3.95 & 3.44 & 4.14 & 3.78 & 5.14 & 3.95 & 5.00 & 0.062 & $4.20^{b} \pm 0.023$ \\
\hline$(g / d l)$ & 4 & 4.24 & 4.07 & 4.45 & 4.69 & 6.04 & 4.47 & 5.85 & 0.062 & $4.83^{a} \pm 0.023$ \\
\hline \multicolumn{2}{|c|}{ Overall mean } & $4.10^{d}$ & $3.76^{\mathrm{e}}$ & $4.29^{c}$ & $4.23^{c}$ & $5.59^{a}$ & $4.21^{\mathrm{cd}}$ & $5.42^{b}$ & 0.043 & \\
\hline \multicolumn{2}{|c|}{ Overall mean } & $3.61^{b}$ & $3.53^{b}$ & $3.85^{a}$ & $3.88^{a}$ & $3.15^{c}$ & $3.82^{a}$ & $3.14^{\mathrm{c}}$ & 0.063 & \\
\hline $\mathrm{AL} / \mathrm{GL}$ & 0 & 1.17 & 0.97 & 1.12 & 0.93 & 1.84 & 1.02 & 1.62 & 0.043 & $1.24^{\mathrm{b}} \pm 0.016$ \\
\hline ratio & 4 & 1.09 & 1.19 & 1.11 & 1.27 & 1.71 & 1.19 & 1.83 & 0.043 & $1.34^{\mathrm{a}} \pm 0.016$ \\
\hline \multicolumn{2}{|c|}{ Overall mean } & $1.13^{b}$ & $1.08^{b}$ & $1.12^{\mathrm{b}}$ & $1.10^{b}$ & $1.78^{a}$ & $1.10^{b}$ & $1.72^{\mathrm{a}}$ & 0.030 & \\
\hline Urea & 0 & 29.92 & 32.13 & 23.15 & 22.99 & 22.73 & 23.33 & 23.05 & 0.417 & $25.33^{b} \pm 0.157$ \\
\hline$(\mathrm{mg} / \mathrm{dl})$ & 4 & 39.15 & 37.64 & 30.38 & 31.23 & 29.96 & 31.40 & 29.85 & 0.417 & $32.80^{a} \pm 0.157$ \\
\hline \multicolumn{2}{|c|}{ Overall mean } & $24.55^{a}$ & $24.63^{a}$ & $23.66^{b}$ & $23.63^{b}$ & $22.84^{c}$ & $23.57^{b}$ & $23.54^{b}$ & 0.167 & \\
\hline $\mathrm{ALT}$ & 0 & 4.75 & 4.75 & 4.62 & 4.55 & 4.00 & 4.62 & 4.37 & 0.163 & $4.52^{b} \pm 0.061$ \\
\hline$(\mathrm{U} / \mathrm{l})$ & 4 & 6.36 & 6.72 & 6.25 & 6.37 & 5.32 & 6.65 & 6.20 & 0.163 & $6.26^{a} \pm 0.061$ \\
\hline \multicolumn{2}{|c|}{ Overall mean } & $5.55^{\mathrm{ab}}$ & $5.73^{a}$ & $5.43^{\mathrm{ab}}$ & $5.46^{\mathrm{ab}}$ & $4.66^{c}$ & $5.63^{\mathrm{ab}}$ & $5.28^{b}$ & 0.115 & \\
\hline
\end{tabular}

Means with different litters with each row and column are significantly different $(P<0.05)$ 